\title{
Grundtvigs nordisk-mytologiske billedsprog - et mislykket eksperiment?
}

\author{
Af Flemming Lundgreen-Nielsen
}

Var det gavnligt for Nordens skiфnne Litteratur, om den gamle Nordiske Mythologie blev indført, og af vore Digtere almindelig antaget $i$ Stedet for den Graske? Således lød den prisopgave, K $\varnothing$ benhavns Universitet udskrev i februar 1800. Universitetet (hvad der her bet $\varnothing \mathrm{d}$ professor i veltalenhed, grammatikeren og sprogmanden Jacob Baden) var måske inspireret af en opsats i Schillers tidsskrift Die Horen, 2. årgang, 1796, med titlen Iduna, oder der Apfel der Verjüngung. Her mente forfatteren, J.G. Herder, at de skarpt tegnede bedrifter i de nordiske myter kunne benyttes i moderne digtning med større fordel end de bløde, melankolske Ossianske stemninger (der især var på mode i Tyskland).

Der indkom tre besvarelser. L.S. Platou, i 1813 historieprofessor ved det nye universitet i Kristiania, fik guldmedaljen for at fremhæve den $\emptyset$ nskværdige bestemthed og harmoni i de græske gudeskikkelser over for en vis rå, gigantisk skønhed hos de nordiske guder - altså en værk-æstetisk bedømmelse. Stud. jur. Adam Oehlenschläger fik første accessit for at svare et rungende ja til spørgsmålet. Det sker principielt i hans allerførste sætning: »At Mythologie i Almindelighed gavner den nye Digter, forudsætter Priisspørsmaalet med Grund, thi den er selv et Produkt af Poesien i sin meest blomstrende Alder. ${ }^{1}$ Dernæst fortsættes og gennemføres drøftelsen ud fra den skabende digters synspunkt, begrundet dels i, at nordisk mytologi ikke er så nedslidt af kunstnere og digtere som den klassiske, dels $\mathrm{i}$, at den kan bringe usynlige ideer i en skøn sanset form. Teologen Jens Møller fik andet accessit for ligeledes at svare ja, men ud fra en uforpligtet læsers synsvinkel, en læser, der vil mores og have nyt stof. Alle tre afhandlinger blev trykt i 1801 i K.L. Rahbeks månedsskrift Minerva, så redaktøren må have haft en fornemmelse af, at emnet ville interessere hans publikum. Grundtvig var lige ung nok til at kunne være med, men et par år efter tog han fat. Det skulle være forbeholdt ham at arbejde på en nyreligiøs forståelse og anvendelse af Nordens gamle myter.

Grundtvigs engagement i den nordiske mytologi er bestemt ikke overset i Grundtvig-forskningen. Hans vej til oldislandsk sprog og læsning af norrøne skrifter, hans ældste syntese af mytologien, hans 
mytologiske billedsprog i egen poesi og prosa, hans brug af nordisk mytologi i udformningen af en universalhistorisk anskuelse, hans elevers benyttelse af nordiske myter i foredrag, højskoleundervisning, politiske og folkelige taler er behandlet både i bredden og i dybden. ${ }^{2}$ Én side har dog fået mindre opmærksomhed: Grundtvigs egen holdning i teori og praksis til muligheden af at indføre nordisk mytologi som et alment anerkendt billedsprog i moderne digtning og åndsliv altså hans bekræftende svar på den prisopgave, han i 1800-01 var for ung og uprøvet til at binde an med, og de praktiske følger, svaret burde have. Udsagn i utrykte og mindre kendte trykte skrifter af Grundtvig vidner om bestræbelser i den retning. De vil her blive betragtet ud fra den samme forståelse for, at mytologien indbefatter heltesagn og de ældste konger, som Grundtvig gør gældende i sine fire håndbøger om emnet $(1808,1832,1844,1847)$. Der tages ikke hensyn til, hvad moderne religionsvidenskab måtte mene om hans mytetolkninger. En væsentlig målestok kan være Grundtvigs vekslende forhold til Snorre Sturlason. Snorre havde omkring 1220 samlet de nordiske myter $\mathrm{i}$ sin håndbog for nationalt sindede kristne isländske digtere, Den yngre Edda, og derved indledt senere tiders benyttelse af stoffet.

Det nordisk-mytologiske symbolsprog blev et af de projekter, som Grundtvig ikke fik ført til noget afgørende gennembrud i sit forfatterskab. Til hans store sorg, for her havde han fra sin tidlige ungdom virkelig investeret sit hjerteblod.

\section{Grundtvigs tilegnelse af nordisk mytologi}

Grundtvig har flere gange overskuet sit forhold til den nordiske mytologi, med lidt varierende resultater, men i hovedtrækkene ens. En bedømmer udefra kan ikke være meget uenig i hans selvkarakteristik.

Den første fase, 1800-1804, betegner han som domineret af en »blind Natur-Drift «. Uden ret at vide hvorfor blev han så tiltrukket af oldislandsk, at han i sommeren 1804 gav sig til at studere sagaer i originalsproget. I mangel af en islandsk-dansk ordbog satte han selv en ordliste sammen fra en tosproget islandsk-latinsk kirkehistorie i faderens bibliotek. 
Næste fase kalder han selv, noget afstandtagende, "Asarusen «, første gang i 1814 (Fasc. 179 4r). Den varer fra 1805 til 1810 (eller foråret 1811), og det er her, han etablerer en episk struktureret oversigt over eddalæren, en syntese. Det er han den første til at gøre i Danmark, mens forgængere som historikeren P.F. Suhm med $\mathrm{Om}$ Odin og den Hedniske Gudelare, 1771, havde skildret gudeverdenen i paragrafform samlet om de enkelte hovedguder, og bogholderen J.B. Møinichen i 1800 havde udsendt et opslagsværk alfabetisk ordnet efter gudernes navne. Grundtvig er inspireret af tyskeren Karl Philipp Moritz' antikke mytologi, Götterlehre, 1791, særligt af den alternative titel oder mythologische Dichtungen der Alten.

Asasynet udtrykker Grundtvig en del gange i de fem år, mest digterisk i tidsskriftartiklen $\mathrm{Om}$ Asalaren, 1807, skrevet på Egeløkke uden tilgængeligt håndskriftmateriale på grundlag af det udkomne stof (den arnamagnæanske (ældre) Edda I, 1787, P.H. Resens (Snorres) Edda, 1665, B.C. Sandvigs oversættelser af eddakvad 1783-85). Ifølge et samtidigt utrykt manuskript er princippet for Grundtvigs tolkning af begivenhederne fra verdens skabelse til Ragnarok og genskabelsen »et lyst Blik og en af Edda selv avlet Ide « (Fasc. 264 1.a $7 v)$. Det lyse blik er den romantiske Ahnelse, intuitionen, og Eddaens idé er identisk med handlingsgangen i Völuspá (Vølvens Spådom), det eneste totalt overskuende eddadigt. I et andet utrykt fragment, $\mathrm{Om}$ gamle Nords skrevne Mindesmaerker og isar om den poetiske Edda (Fasc. 257), erklærer Grundtvig, at han er »delt mellem Beskuelse af det Hele og Gransken i det Enkelte«, og forsikrer, at gamle Nord er »min Aands Hjem, at jeg derfra laaner alle de Billeder hvori jeg beskuer det Usynlige« (2r). Dette er en eksistentialistisk brug. Og her er de dunkle eddakvad, som tilsyneladende svarer til den romantiske æstetiks begreb om frugtbar dunkelhed, vigtigere end den yngre Edda, om hvilken Grundtvig i sin dagbog for 24. juni 1807 tørt noterer: »Jeg fik Snorres Edda, harmedes over den, men fandt dog Lidet i samme« (US I, s. 114).

I maj-juni 1808, da Grundtvig er flyttet fra Egeløkke til København i nærhed af håndskriftsamlingen og de lærde biblioteker, skriver han i et andet manuskript, Om den nordiske Mythologies Kilder (Fasc. 258): „Spørgsmaalet er ei om Fædrene have dyrket Guder med disse eller hine Navne, en i sig selv saare ubetydelig Omstændighed, men om de igennem Guderne, som dyrkedes, søgte at forstaa Tilværelsen dens Udspring og Øiemed« (1v). I Nogle Trak af en Sam- 
menligning mellem den graske og nordiske Gudelare (Fasc. 255.1) bliver resultatet en påvisning af forskellen mellem græsk og nordisk mytologi - »der hvor Gudelivet er et idealiseret Menneskeliv og der hvor Menneskelivet er en Stræben op til Gudelivet « (2v). Og da han fra 1 . november 1808 underviser i historie på den moderne københavnske Schouboeske skole, lærer han sine elever: »Hvad Livets Ideal er hos et bestemt Folkefærd, kunne vi altid med Sikkerhed slutte af dets Gudelære « (Fasc. 211.10 221r). Om grækerne fortæller han således sin klasse, at da deres ideal var nydelse af menneskelivet, er de rige i fabellæren (om livsytringerne), fattige i gudelæren og tomme i deres opfattelse af tilværelsen i dødsriget som én ulykkelig længsel efter det tabte jordiske liv. Denne bevidsthedshistoriske vinkel fastholder han hele livet. I fortalen til bind I af Saxo-oversættelsen i 1818 ræsonnerer han om Saxos mytegengivelser, at

[..] en grundig Eftertanke over de menneskelige Vilkaar vist skal bevise, at saadanne Sagn umuelig kan opstaae, elskes og giemmes hos et Folk, der ei havde Hjertelag til at giøre, hvad de melde, samt at et saadant Hjertelag umuelig kan findes uden at tee og yttre sig i tilsvarende Handlinger, efter Tidernes Vilkaar og Leilighed [..]

(US IV, s. 94)

Endnu i tidsskriftet Danskeren hedder det tilsvarende i 1850:

[..] ethvert Folks saakaldte Mythologi eller Gudeleg viser os med Nødvendighed de høieste Tanker, Folket har havt om Menneske-Livet, da det naturligviis var deres eget Liv, de $\mathrm{i}$ Tankerne om deres Guder stræbde at forædle og forgude.

(III, s. 247)

Femårets hovedværk er Nordens Mytologi, 1808. Grundtvig betoner i 1815 i et brev til den yngre ven S.J. Stenersen i Norge, at asarusen først og fremmest gælder 1807-artiklen, mens bogen året efter er i »den rolige, betænksomme Tone« (Br I, s. 316).

Grundtvig når frem til nogle vigtige resultater. Ved hjælp af det lyse blik og Eddas egen idé sondrer han mellem ældre og yngre kilder. Det er i forhold til forgængeren Suhm vigtigt, at Grundtvig søger at datere kilderne. Imidlertid sætter han det subjektive over det muligt 
objektive, så tolkerens begejstrede sindsbevægelse under det aktive arbejde med forståelsen bliver bevis på, at han har ramt en ægte kilde. I $\varnothing$ vrigt mener Grundtvig i et samtidigt fragment (Fasc. 260), at Vølvedigtet må være fra det 5. århundrede - altså i moderne forstand jævnaldrende med den urnordiske runetekst på det ene af guldhornene fra Gallehus! Videre anser han mytologien for et værk af én digter - en gammel vismand, som midt $\mathrm{i}$ verdens storme og ubegribelige ondskab søger at forklare linjen i begivenhederne trods alt. Den er »ei opstaaet ved Refleksion over Fænomenernes Indtryk paa de ydre Sanser, men fremsprunget ved Livets og Tidens umiddelbare Beskuelse« (US I, s. 339). Da denne digters glasst $\varnothing t t e$ af tiden er forvandlet til sten, må en moderne poetisk gransker forvandle den til gennemsigtigt glas igen. Det sære billede er lånt fra eddadigtet Hyndluljód. Endelig ser Grundtvig over de enkelte guder eneherskeren Alfader, som regerer via nornerne. Hertil kommer, at Grundtvig allerede i 1807 finder det særligt for Nordens guder, at de ikke kan uddifferentieres: »de ere Eet. [..] Punkter i samme Linie« (s. 207).

Grundtvig arbejder på dette tidspunkt mest med mytologien som videnskabsmand. På baggrund af den arnamagnæanske eddaudgaves tilsyneladende forlis efter bind I, 1787, tilbyder han faktisk både en videnskabelig tekst af Völuspá og en ny oversættelse (s. 257 note ${ }^{*}$ ). Den store opgave er for ham rekonstruktionen af myternes oprindelige helhed ud fra kilderne, mindre en nutidig anvendelse af dem. Snorres Edda bliver for ham derfor kun »Mytologiens Forgaard« (s. 250). Snorres fortælling om Thors rejse til Udgårdsloke betegnes som en begivenhed, der savner betydning i det store asadrama fra verdens tilblivelse til Ragnarok og genskabelsen, skønt det kan være underholdende nok - især i Oehlenschlägers gengivelse (Nordiske Digte, 1807). Balders død er »dels udmalet, dels forvansket«, gjort usand og uforenelig med asalivet $\mathrm{i}$ en række enkeltheder (s. 287-290). Andre karakteristikker af mytologiske detaljer hænger Snorres Edda ud for »de elendige Eventyr, Blindhed og Sløvhed avlede«, for usselhed og flovhed, så man må væmmes (s. 281 note *, 283). Snorres inddeling af alferne i lysalfer og mørkalfer er »den yderste Forvirring [...], neppe [..] andet end en Anvendelse af Englelæren« (s. 346). Om Loke, der fik munden syet sammen, hedder det: »Dersom en Kristen ei har vævet dette, da har det hjemme i en Epoke, da Man kunde tro, at Symboler kunde komme udenfra« (s. 351-352). I en samtidig kritik 
af idéen bag Oehlenschlägers Baldur hin Gode, 1807, føres et gennemgående fejlsyn hos digteren netop tilbage til hans brug af Snorres $E d d a$ i stedet for »den eneste ægte Kilde: Vegtams Kvide« (Ny Minerva for december 1807, udsendt forsinket i april 1808, s. 309).

Der er dog to positive kommentarer til Snorre. Hans gengivelse af Hymiskvað $i$ har »sin fuldeste Betydning « og er skrevet i sød stil med barnlig tro på guderne (US I, s. 322). Og hans afsnit i den »berygtede Fortale om Jordens Liv $\ll^{3}$ kan Grundtvig ikke nægte sig selv den glæde at afskrive (s. 346-347) - vel fordi den præsenterer hele jorden som én stor levende organisme, hvad Steffens også havde gjort i sine forelæsninger over romantisk naturfilosofi ${ }^{4}$.

Et initiativ med en ordret oversættelse af den ældre Edda i januarfebruar 1810 strander uhjælpeligt på en skarp offentlig kritik af princippet fra Rasmus Rask. Og efter Grundtvigs krise i julen 1810-11, der ender i en bibelkristendom, skydes mytologien i baggrunden. Da Grundtvig fra 1812 er engageret af Selskabet for Norges Vel til at oversætte Snorre, gælder det ikke Edda, men hans historiske krønike om norske konger, Heimskringla - først kvadene, siden også prosaen.

Grundtvig reagerer således ikke på Jens Møllers opsats Om den nordiske Mythologies Brugbarhed for de skjønne tegnende Kunster, trykt i Det skandinaviske Litteraturselskabs Skrifter, Ottende Aargang, 1812, s. 225-301. Fra Udby skrev han ganske vist i tiden december 1812 til 6. april 1813 lange breve til Møller, men de angik kristendommen og Grundtvigs Verdenskrønike 1812 (Br I, s. 134141, 159-173).

Jens Møllers tekst er ellers en god målestok for, hvor langt forståelsen af nordisk mytologi er nået. Han fastslår generelt, at bildende kunst må være både skøn og klar, så emnet umiddelbart kan identificeres, eventuelt ved hjælp af symboler (s. 229-231). Forbilledet er klassisk: "Antiquen bør formedelst dens uovertræffelige Høihed i Aand, dens Simpelhed i Maneer og fuldendte Fiinhed i Udarbeidelse, til evig Tid tjene den bildende Kunstner til Norm« (s. 241). Med Chateaubriand hævder Møller imidlertid, at »det er af høieste Vigtighed for Kunstværkernes Effect, at Sujettet dertil, saavidt mueligt, er nationalt« (s. 244, med henvisning til Genie du Christianisme, II, 1807, s. 236). Derfor kan Møller forsvare en moderne genoptagelse af nordisk mytologi ud fra tre synspunkter. For det første byder den på interessantere nye genstande, og mens Møller anbefaler læsning af nationalskjaldene Ewald, Pram og Oehlenschläger, protesterer han 
imod, at Grundtvig i Nordens Mytologi, 1808, fraskriver de nordiske guder individualitet (s. 263-269). For det andet møder den nordiske mytologi i dag et vidende publikum, så hvor Ewald måtte tilsætte forklarende noter, kan Oehlenschläger forudsætte indsigt - »vore Damer selv ere blevne fortrolige med Valhals Guder og Optrin « (s. 274). Han efterlyser i samme åndedræt en ny Saxo-oversættelse fra historikeren G.L. Baden. Grundtvigs håndbog kaldes »et System, der baade fordi det er det første og fordi det indeholder saa meget Selvtænkt, altid vil geraade Forfatteren til stor Ære« (s. 277), og Møller glædes ved kunstnerne Abildgaards og Wiedewelts flid og geni i at gengive de nordiske guder. For det tredie kan der hentes nye idealer og nye symboler i nordisk mytologi. Hedenske symboler kan, mener han, godt indgå i kristen sammenhæng som midler - svarende til praksis $\mathrm{i}$ italiensk billedhuggerkunst - dog bedre uden for end inde $i$ kirkerne. Især Grundtvig og Oehlenschläger har bevist, at der ligger dyb mening bag myterne. »Og for at finde dette oftere, behøver man kun at trænge ind til Ideen, hvorom Fabelen dreier sig, istedetfor at blive hængende ved Skallen, Ideens Hylster « (s. 290). Grundtvig har ret $\mathrm{i}$, at mange nordiske guddomme sikkert kun er "personificerede Digterideer « som hos romerne. Af attributter kan en kunstner »benytte Alt, hvad der med nogen Rimelighed kan henføres til Oldtiden « (s. 292) - digtekunstens gud Braga kan have en simpel harpe under armen, men det kræver en Raphaels geni at komme godt fra en Apollo udstyret med violin. Jens Møller ser afsluttende frem til det store billedværk med 48 nordisk-mytologiske kobberstik, tyskeren F.D. Gräter har under forberedelse (det blev nu aldrig til noget). Han håber, at nordiske og danske kunstnere senere vil passe, pleje og benytte »dette herlige Arvegods fra Fædrene til Nationalcharacterens Oplivelse og Forædling« (s. 299). Møllers lange afhandling er vidnesbyrd om en voksende tolerance over for nordisk mytologi. Grundtvig slutter sig til en sådan ufanatisk holdning i sin tredie mytologiske fase, der strækker sig over resten af hans liv.

\section{Grundtvig frisatter mytologien}

Året 1815 markerer Grundtvigs tilbagevenden til nordisk mytologi, men med ændret fortegn, så dens aktuelle udtryksmuligheder sættes over dens oprindelige mening. 
Trods hård kritik af sig selv i brevet 19. april 1815 til Stenersen bekender Grundtvig, at han endnu har »Forkiærlighed for disse Billeder « (Br I, s. 315). Efter optryk af sine objektive lejlighedsdigte i den retrospektive samling Kvaedlinger, udsendt 1 . juli 1815 , skriver Grundtvig i en lang ny gendigtning af Prymskviða, Thryms Kvide eller Hammervisen: „Nu har jeg tiet længe / Alt med min Mythesnak «. Han kritiserer sit gamle digt om asken Ydrasill fra 1808, for skønt træet utvivlsomt er »Tidens Sindbillede«, har den videre udlæggelse »ingen Hjemmel i Edda, og tildeels ingensteds hjemme, uden i et taaget Øie« (US III, s. 121; I, s. 370). Sammesteds berører han flygtigt muligheden af »en anden Udgave« af 1808-mytologien.

Endelig meddeler Grundtvig 2. juledag 1815 i Frederiksberg kirke, at han ikke vil prædike mere som gæst $\mathrm{i}$ hovedstadens kirker, så længe kongen ikke vil kalde ham til en af dem. Samtidig erklærer han rent ud i avisindlæg i Nyeste Skilderie af Kjøbenhavn, at siden selv sympatiske læsere er gået fejl af hans direkte kristne forkyndelse i vers og prosa, kan han lige så godt vende tilbage til en mangetydig og symbolladet poetisk udtryksform. Dette kommer også til at gælde hans forhold til sine oversættelsesprojekter (Snorre fra 1812, Saxo fra januar 1815 og Beowulf fra sommeren 1815). Han foretrækker fra nu af »Fordanskning «, en intuitivt indfølende gendigtning, i stedet for en nøjagtig oversættelse.

Det betyder, at Grundtvig på ny kan udnytte mytologien, men også, at han fra nu af vender sig bort fra den eksklusive videnskabelige forståelse af kilderne i disses egen interne verden. Han kan tolke myterne mere frit, mere løsrevet fra original sammenhæng - for så vidt mere tilfældigt.

Under sin deltagelse i tylvtestriden, fejden mellem Baggesen og Oehlenschlägers beundrere $\mathrm{i}$ de sidste tre måneder af 1818 , kalder Grundtvig i et af de utrykte manuskripter (Fasc. 180.1) nordisk mytologi for

min Aands naturlige Speil, min poetiske Side, Brænd-Punkten hvori alle Straaler som skulde tænde hos mig maatte samle sig, Middel-Punkten altsaa for min aandelige Virksomhed, mit SkatKammer saavelsom mit Rust-Kammer. 
Hvis asalæren kunne være for nordboen, hvad Det Gamle Testamente er for den kristne, ville Grundtvig få et særegent billedsyn og billedsprog til at »kvæde efter Hjertenslyst uden at fornærme ChristenDommen« $(42 \mathrm{r}-\mathrm{v})$.

De krævende oversættelser fuldføres på forbløffende kort tid 18151823. Samtidig udgiver Grundtvig i fire bind Danne-Virke, 1816-19. Det var praktisk talt et énmands tidsskrift, i hvis prosa han beskæftiger sig meget med dansk (sagn)historie, men næsten ikke med nordisk mytologi. Dog hedder det i artiklen Et Par Ord om Oldgrandskning fra august 1817, at det er en kristen tilladt at sysle med hedenske myter, når det sker med et højere mål for $\varnothing j e$, men at det var en fejl, at Grundtvig 1806-08 ikke forbandt nordisk mytologi med historien. Tilbageskuende mener Grundtvig, at Nordens Mytologi, 1808, var »saa ædrue og betænksom, som man burde ønske«, kun skulle han have »forbedret og fortsat « den. Grundtvig tilføjer, i strid med den herskende videnskabelige opfattelse, at de islandske sagn er »ligesaa usikkre og blandede som Saxos« (US III, s. 516). I et følgende bidrag tolkes Fornjótur-myten som en skildring af Norges fysiske tilblivelse. Det i enhver forstand blandede digt Ragna-Roke, (et dansk Amter) i Danne-Virke, III, 1817, er et klart vidnesbyrd om en friere holdning til mytologien.

Vigtigt er det, at Grundtvig herefter bliver mere og mere interesseret i Snorres Edda. I fortalen til sin Heimskringla-oversættelse, I, 1818, skriver han, at Snorres forfatterskab til Edda endnu ikke er bestemt afgjort, "men vist nok kunde det ligne ham, paa en saa forstandig Maade at benytte de ældgamle Sange, der maatte være udelukkede af den Historie, han skrev«, for Eddaens indhold måtte udgøre »en nødvendig Indledning til Norges Krønike«. Da man på Island aldrig har nævnt anden forfatter til Edda end Snorre, bør han anses for det, indtil det modsatte bevises (US IV, s. 157).

\section{Nordens myter $i$ bildende kunst?}

Omkring 1820 blusser debatten fra Ewalds sidste leveår om de nordiske myters brugbarhed for nyere bildende kunstnere ${ }^{5}$ op igen i $k \varnothing-$ benhavnsk presse og pamfletlitteratur. Den umiddelbare anledning synes at være Thorvaldsens ophold i København fra oktober 1819 til august 1820. Han blev modtaget af studenterne ved en fest 16 . 
oktober 1819 på Den Kgl. Skydebane. Oehlenschläger, der i juni havde udsendt sin samlede digtning om myterne, Nordens Guder, bad ham i en tale om en gang imellem at tænke lidt på Nordens gamle gudeskare; hertil skal billedhuggeren have svaret, at han ikke vidste, hvad han skulle give guderne på. Thorvaldsen forelæste siden på Kunstakademiet og blev selvsagt feteret.

Allerede i 1814 var Kunstakademiets fundats blevet fornyet med blandt andet en paragraf om undervisning i nordisk mytologi. Efter kongelig befaling af 10. april 1819 holdt professor Finn Magnussen på akademiet nogle indledende arkæologisk-historiske forelæsninger, der i 1820 udkom i bogform som Bidrag til nordisk Archaoologie. Ved en lidt for optimistisk udnyttelse af sagaernes og andre middelalderlige kilders udsagn om nordisk kunst og kultur i den hedenske oldtid lykkedes det Finn Magnussen at tilvejebringe et omfattende bevismateriale for hjemlig udvikling og originalitet. Han klarede også efter en gennemgang af Ólaf Pás billedsal at få nævnt Thorvaldsen som dennes efterkommer i 25. led (s. 36). Han sluttede hele sin gennemgang med en appel til moderne åndfulde kunstnere om at gå i de nye digteres spor og genvække de hjemlige guder, så »vore Øjne skulle see de herlige Syner, som hidindtil kun forlystede Aandens Blik« (s. 207). Garantien herfor er, i Magnussens højstemte stil, netop Thorvaldsens europæiske ry:

Aldrig er dog den Naturen forædlende Kunstsands veget fra vore Egne; Endmindre kunne vi nu befrygte at det fremdeles vil skee. Fra Norden opsteg den straalende Sol, som fordunkler selv de største Kunstens Lys, ved hvis Skin Aartusender frydedes og undervistes. Gothen har gjenvundet Grækerens Krands ved at efterligne hans herlige Mønstre og Hedenolds sydlige Guddomme - nu vove han og at opløfte Øjnene til sine egne.

(s. 207-208)

Den tilsyneladende støtte fra højeste sted til en institutionel virkeliggørelse af synspunkterne fra Jens Møllers skrift om mytologiens brugbarhed fra 1812 kaldte de to iltre brødre Torkel og G.L. Baden frem til en fejde, der mere skulle præges af impulsiv modstand end af saglige indsigter.

Professor Torkel Baden fungerede fra 1804 som sekretær ved Kunstakademiet, indtil han i 1823 måtte tage sin afsked på grund af 
samarbejdsproblemer. Han lancerede en række pjecer imod den nationale mytologi som kunstnerisk sujet. Allerede Om den nordiske Mythologies Ubrugbarhed for de skiфnne Kunster, 1820, egentlig en ripost til Jens Møller, som Baden havde haft liggende færdig i sin pult $\mathrm{i}$ fire år, afsiger den definitive dom: her »vil Kunsten finde sin Grav« (s. 6), for »Vanskabt, for Phantasien ubrugbart er Alt, hvad den nordiske Mythologie indeholder « (s. 18). »Lad Gräter ophøie, saa meget han vil, Ran og hendes Garn, fuld af Skibbrudne. Kunstneren foretrækker Havets Gud. I Neptuns vrede Blik maler sig det brusende Element« (s. 19). "Skiønhed er Kunstens Middelpunkt, og Grundvolden til det Nøgnes Tegning « (s. 20), fastslår Baden.

Finn Magnussen gav igen med Bemarkninger ved Hr. Prof. Torkel Badens Skrift om den nordiske Mythologies Ubrugbarhed for de skjønne Kunster, 1820. Det er en gendrivelse af Baden først og fremmest med det sigte at påvise dennes ukyndighed i nordisk mytologi - hvad der er en forholdsvis let sag. Baden indvender eksempelvis, at Freja er skildret som en ulækker grovæder, men han har helt overset, at det i kilden (Prymskviða) drejer sig om Thor i forklædning (s. 27). Magnussen minder om, at græske myter også engang var rå og primitive: „Det var store Digteres, Philosophers og Kunstneres ophøjede Genie som, ved forenede Bestræbelser, gav den græske Gudelære dens varige og almindelige Brugbarhed. Bliver Spørgsmaalet derimod om national Interesse, saa kan vel den nordiske, hos Nordboerne, nu gjøre Fordring paa en større Opmærksomhed, end Fleerheden havde viist den i en Række af Aarhundreder « (s. 43). For resten citerer Magnussen Thorvaldsen for en mundtlig udtalelse imod det formentlig uskønne ved Frejas katteforspand: »hin Indvendning var ugrundet, da den aandfulde Kunstner vilde vide, ved en saadan Afbildning, at give Freyas Katte skjønne tigeragtige Former, og derved tillige en saadan Karakter, som kunde interessere en tænkende Betragter« (s. 12-13).

Baden og Magnussen udkæmpede nu en rap duel i indlæg i Nyeste Skilderie af Kjøbenhavn 28. november, 5., 12., 16., 26. og 30. december 1820. Magnussen hævder her, at af kunstnerne er det kun C.F. Høyer, som støtter Baden (sp. 1553-1556). Baden svarer, at han også har C.A. Lorentzen, C.W. Eckersberg, J.L. Lund, J.Fr. Clemens, Chr. Hornemann, C.D. Frizsch, J.P. Møller, C.D. Gebauer, Arnold Wallick og A. Jacobsen bag sig (sp. 1593). Det er kunsthistorisk vurderet ikke noget imponerende opbud. Magnussen kommer tilbage 
i blidere tone med udtalelser fra Thorvaldsen og Eckersberg om også at gøre sig bekendt med hjemlig mytologi (sp. 1604-1605), men Baden kan atter overgå ham: Thorvaldsen skal have rost Abildgaards menneskegestalt på maleriet (fra 1777) af koen Audhumbla, men beklaget symbolikken $i$, at det nordiske menneske fødes af »den ludende Ko [..] Dumheden selv« (sp. 1649). Baden pointerer ligeledes, at de to lærde, Møller og Magnussen, begge er fremmede for kunstens verden (sp. 1527).

Pseudonymet L. Jacobsen udsendte i 1820 pjecen Professor Finn Magnussens Beviis for, at vore Kunstnere ved Rejser til Iisland kunde naae det Samme, som ved at rejse til Italien eller Rom, 1820, der ved udvalgte Magnussen-citater uden for kontekst, tilmed forsynet med 48 sønderlemmende noter af udgiveren, fik de særeste udsagn frem som dennes autentiske mening.

Svaret fulgte i en skarp tone i pjecen Udførlig Erklaering fra Professor Finn Magnusen i Anledning af et pseudonymt Flyveskrift, 1820. Magnussen forsvarede sig med rette mod citatfusk og falskneri og påberåbte sig dels de kunstgenstande med nordisk, ikke romersk, præg, han havde rundsendt blandt tilhørerne til sine forelæsninger, dels historikeren G.L. Badens værk Udkast til en Historie om Danmarks og Norges Handel og Naringsveje fra Oldtiden til Nutiden, 1806. Pointen heri var, at pseudonymet netop var et skalkeskjul for Torkel Badens broder G.L. Baden, søn af professor Jacob Baden og derfor efter islandsk navneskik en $»$ Jacobsen $«$.

$\mathrm{Nu}$ rykkede Gustav Ludvig Baden ud i eget (fulde!) navn med støttepjecen L. Jakobsens Forsvar mod Hr. Professor Finn Magnusen, 1820. Den er fuld af generelle deklamationer imod det fordærvelige islandske uvæsen i vor litteratur og påstår, at kun få kunstnere, ja »tilsidst ingen, udholdt til Enden Deres Forelæsninger« (s. 9). Han konkluderer barsk: »en islandsk eller oldnordisk Kunsthistorie er en Uting, og Hr. Professorens Forelæsninger herover paa vort Kunstakademie unyttige og tidspildende « (s. 16). Herpå udsendte Magnussen Svar mod L. Jacobsens eller G.L. Badens Forsvar, 1820, hvor han især gendriver påstanden om, at kunstnerne faldt fra ved hans forelæsninger, som aldeles uefterrettelig - uden dog at give navne på de "meget udmarkede Kunstnere" (s. 12-13), der jævnligt beærede ham med deres nærværelse. Her som i det hele taget under fejden betoner Magnussen kraftigt, at han forelæste på kongens befaling. Samme G.L. Baden blev i $\varnothing$ vrigt i august 1820 afsløret for kassemangel, 
flygtede til Norge 1822, men blev udleveret og dømt til ét års fængsel og afskedigelse fra sit embede som birkedommer i Hørsholm resten af sit liv levede han som privat historiker. Kampen om kongens gunst og simpelt brødnid er utvivlsomt blandt ingredienserne $\mathrm{i}$ striden.

Imens fortsatte Torkel Baden sin kampagne. I skriftet Den nordiske Mythologies Kilder, 1821, afleder han hedenskaben af antik kultur og Bibelen, men forarges over, at de nordiske guder ikke som de græske tager virksom del i menneskelivet: de skildres som »Nisser, Trolde og Tusindkunstnere « (s. 18). Hans baggrund er klassikken: »Om ikke andet holder ham [dvs. kunstneren] fra den nordiske Mythologie, saa holder Costumet ham derfra. Nordboen klædte sig i Huder, eller i Vadmel og andet grovt Tøy« (s. 27). Den slags skikkelser lader sig ikke afbilde: »Man vil sige om saadanne Malerier, at de ere opfundne af Druider, og malede af Chinesere« (s. 28). De nordiske Guders Balgm $\phi r k e, 1821$, henviser resolut patrioterne til at læse Bibelen og Homer i stedet for eddaer og sagaer, mens nordiske myter kaldes »Beensuppe og Hestekjød» (s. 16). Nials Saga, den bedste af alle Sagaer, 1821, karakteriserer hånende denne tekst som »en Sammendyngning af Mord- og Spøgelseshistorier; intet videre « (s. 5), altså foragteligt vås på linje med brødrene Grimms tyske folkesagn. Endelig standsede Baden drøftelsen med Et Par Ord til Beslutning om den nordiske Mythologie, 1821, hvor han fastholdt, at aserne skulle kunne fremstilles lige så nøgne som olympierne (s. 4). Kan det ikke ske, så: »Lad Antiqvaren beholde Nordens Guder for sig selv; Kunstneren har intet at skaffe dermed « (s. 28).

Finn Magnussen gjorde modstanderens sagkundskab op i pjecen Oplysninger om Kilderne til Hr. Professor Torkel Badens Sammenligning mellem den nordiske og den grask-romerske Mythologie, 1821. I 40 parallelsteder trykt på store kvartsider afslørede han, at Badens viden om myterne - uden angivelse - var hentet fra den berygtede svenske historiker Olof Rudbecks Atlantica, II, 1689. Dog med den forskel, at Rudbeck ville aflede græske myter af de hyperboræiske (nordiske), Baden gjorde det omvendte. Magnussen må beklage, at nordisk mytologi ikke i sin blomstringstid blev dannet ved $h \varnothing j$ kunst og overleveret $\mathrm{i}$ »artistisk-billedlige Forestillinger « (s. 19) - men det samme gælder jo hebræerne i Det Gamle Testamente og man kan nok stole på gamle sagn og digtninger. Han anfører, at oldtidens rige og fornemme nordboer yndede prægtige dragter, men 
naturligvis svømmede og badede nøgne. »Gudernes Opholdssteder mentes ellers at være saa lyse og varme, at de ikke behøvede at fryse (hvis Guder ellers kan lide af Kulde) skjønt de ikke vare tilhyllede af Klæder og Pelsværk. - « (s. 24).

Den besindige oldforsker, professor P.E. Müller anmeldte Torkel Baden i Dansk Litteratur-Tidende, 1821, ved netop at sammenligne hans "fremsatte umodne Domme « (s. 522) med Rudbeck og afvise hans brug af det nøgne i græsk kunst som en målestok for god smag, når det gælder oldnordiske myter. Om det sidste fortsætter han: »Men mon vel Barometret stod høiere paa Olympen end i Valhalla? mon ikke Kunstneren ligesaavel kunde betjene sig af det Nøgne ved Asernes som ved Olympiernes Fremstilling?« (s. 518). Baden demonstrerer i det hele, at "han mangler den for en Humanist vigtige Egenskab, at kunne sætte sig ind i en gammel Tidsalders Tænke- og Handlemaade« (s. 524).

Af kunstnerne selv deltog C.F. Høyer, kongelig historiemaler med et såre beskedent talent. Han samlede sine indlæg fra avisen Dagen i skriftet Tilegnet Det Kongelige Kunstacademiets Medlemmer og unge Kunstnere, 1821. Han anfører, at græsk mytologi med de »sindrige Emblemer, philosophiske Billeder og forstaaelige Allegorier « (s. 6) er man nødt til at lære for at nyde og nytte kunsten fra menneskehedens mest kultiverede tidsalder, mens nordisk mytologi er tidsspilde for kunstneren - altså en tilslutning til brødrene Badens bersærkergang. I $\varnothing v$ rigt blev Høyer i 1826 ekskluderet som akademimedlem for udisciplineret optræden.

De to Baden'er var kendt som kantede størrelser. Müller nævner i sin recension, at professor Rahbek, Universitetets første lærer i æstetik, har afvist på embeds vegne at blande sig i striden. Desto bemærkelsesværdigere er det, at Grundtvig har tænkt på at melde sig med et indlæg i Nyeste Skilderie af Kjфbenhavn, bevaret i udkast (Fasc. 262). Det hedder Om Afbildning af Nordens Myther.

Udgangspunktet er, at »begge Partier turde have skiænket det egenlige Spørgsmaal meget for liden Opmærksomhed« (1r). Da Grundtvig selv, modsat Baden, virkelig er mytologisk sagkyndig, vil han ytre sig. Indledende understreger han, at ingen har påstået, at danske kunstnere udelukkende skulle beskæftige sig med nordiske myter og gengive dem alle; det ville også han anse for galskab.

Påstanden, han vil drøfte, er alene, »at det var ønskeligt, om Danske Konstnere kunde faae Lyst til at ændse og bruge Nordiske My- 
ther, hvis Fremstilling, naar den lykkedes, maatte faae visse eiendommelige Fortrin og et mere hjemligt Anstrøg« (1v). Svaret kan Grundtvig kun se i, om fremstillingen duer noget eller ej, og derfor går det over hans forstand, at Kunstakademiets talsmænd nærmest vil forbyde kunstnere overhovedet at gøre fors $\emptyset$ get. De nægter altså de nordiske myters brugbarhed uden at have afbevist den. At de omtalte kunstnere (Høyer og Eckersberg) ikke har lyst eller kundskab nok til at arbejde med det gamle Nord, er ikke opsigtsvækkende, for »det er ikke Hvermands Sag at bryde nye Baner«; de bør ikke tillægge sig en så stor selvsikkerhed, at de kalder umuligt for alle, hvad der er det for dem; endelig ser Grundtvig ikke, »at Nogen af de Konstnere, som i denne Sag har givet os deres Tykke, nogensinde har viist, at de kiendte Nordens Myther, eller havde Sands for det Poetiske deri, to Ting, som dog nødvendig udfordres for at kunne have nogen Stemme-Ret « $(2 \mathrm{v})$.

Til sidst går Grundtvig polemisk frem mod en udtalelse af Baden i Den nordiske Mythologies Kilder, 1821. Her havde denne først hånende udbrudt: »Skulde det sande Studium af den menneskelige Skikkelse, det Nøgne, blot indskrænke sig til Ansigtet, og det Øvrige tildækkes med Draperier af de munterste Farver?«. Dernæst havde han triumferende mindet om, at $\mathrm{W}$. Tischbein gjorde således ved sine illustrationer til (Klopstocks) Hermannsschlacht, men snart vendte tilbage til det nøgne græske (s. 27). Grundtvig skelner mellem en kristen og en kunstnerisk holdning: »Om det Nøgne kan jeg fatte mig kort; thi deels skulde jeg dog mene man kan finde et paaklædt Menneske kiønt, naar kun Ansigtet er bart, og deels maatte hiin Paastand, hvis den var grundet, ikke blot bevise den Nordiske Mythologies men hele Historiens Ubrugbarhed for Konsten; eller, rettere sagt, kun det Sidste; thi var det ellers sømmeligt blandt Christne, hvad jeg benægter, at fremstille nøgne Billeder, da veed jeg ikke, hvad der skulde hindre Konstneren i, at tage sig den Frihed med Nordens Guder« (3r). Her afbrydes indlægget. ${ }^{6}$

Hvad kan Grundtvig have villet på denne galej? Han satte jo ellers de bildende kunster lavest som de kødeligste og mest materialistiske af alle, ville næppe kalde sig selv en relativistisk indstillet humanist og skulle nok være den sidste i samtiden til at mene noget om det nøgne i kunsten. Forklaringen kan være tredobbelt. For det første havde Torkel Baden $\mathrm{i}$ bogen om den nordiske mytologis kilder med navns nævnelse hængt Grundtvig ud for vilkårligt at have ændret 
navneformen »Häner « til »Løter «: »Det kalder man at skjænde og brænde; som bekommer en Kritikus meget ilde« (s. 9). For det andet følte Grundtvig sig åbenbart kaldet til en opmandsrolle i den københavnske opinion, ligesom han i de sidste tre måneder af 1818 havde søgt at skabe klarhed og orden i begreberne i tylvtestriden mellem Jens Baggesen og Oehlenschlägers tilhængere. For det tredie var han stadig - eller igen - stærkt engageret i den mulige praktiske brug af de nordiske myter. Det beviser hidtil mindre påagtede manuskripter fra disse år. ${ }^{7}$

\section{Mytologiske fragmenter og initiativer 1821-25}

Mythologiens Vard (Fasc. 253) drøfter emnet i almindelighed ved fors $\varnothing$ gsvis opstilling af en regulær teori. ${ }^{8}$ De hedenske forestillinger er måske »vildfarende « $\mathrm{i}$ forhold til sand religion, men ikke »løgnagtige« (1r) - og vildfarelserne er godartede:

Saa nær altsaa som Ærlighed ligger ved Sandhed, Medynk og Gavmildhed ved Kiærlighed, Djærvhed ved Frimodighed, saa nær ligger den mythiske Forestilling om Menneske-Værd ved den rette, saa man kan sige, hvem Nordboen kaldte slet, han var det tilvisse, og hvem der kaldtes den Bedste, var en ædel Sjæl, men Mange kaldtes gode, som var kun glimrende, og med Kraften var man langt fra at regne saa nøie som Sandhed og Kiærlighed byder.

For »Folkene skabe deres Mythologie ei blot efter deres eget Hoved, men ogsaa efter deres Hjertes Lyst, og lade derfor den Idee de elske meest fortrænge den dertil odelsbaarne fra Høisædet « (3v). Som i afhandlingerne 1806-08 opfatter Grundtvig thurserne som udtryk for egenkærlighed, som aserne i stedet for at bekæmpe besvogrede sig med og derfor blev offer for:

Dette er Grunden hvorfor man med Rette kan kalde Nordens Mythologie universalhistorisk fordi den er en Opfattelse af den historiske Menneske-Kamp som finder Sted til alle Tider, og hentyder paa en Seiervinding, hvorved det Slette forgaaer og en 
Omsmeltning hvorved det Ædle renses. Kæmperne ere som de Guldkorn Floderne føre med sig, de renses i Løbet og beh $\varnothing$ ve kun at sammensmeltes, mens Guderne ere som den ædle Malm i Klipperne som end haver fiendtlige Dele i sig, til den smelter i Surturs Lue.

$(6 r-v)$

Han fortsætter:

Hvorvidt nu en saadan Mythologie skal have poetisk Brugbarhed, beroer aabenbar kun paa, hvorvidt de enkelte Skikkelser og Optrin er i det Heles Aand, hvorvidt nemlig de enkelte Guddomme ere store Individualiteter der udtrykke en hel KæmpeArt eller Helte-Slægt saa de tilsammentagne udtrykke alle de caracteristiske Forskielligheder, som opkomme ved forskiellig Blanding af de samme Elementer, og hvorvidt Gudelivet er en tilsvarende Yttring, eller en symbolisk Skildring af de store Afsnit der findes i Menneske-Kampen af aandelig Rod og med aandeligt Øiemed. Er dette Tilfældet da er Mythologien ei blot brugbar men $\varnothing$ nskelig som Symbolik for de Folkefærd den tilhører lige til Verdens Ende, thi den oplyses da kun stykkeviis i Tidens L $\varnothing b$ og forklares først paa den yderste Dag.

I lys heraf tolker Grundtvig Ragnarok som en »vel dyb men dog vildfarende Ahnelse om den store Forvandling og Forklaring, vi som Christne kiende anderledes godt, og kan ei bruge de hedenske Drømme til at betegne; thi vi veed, at hvad som da forgaaer er kun det Onde, som aldrig meer opstaaer «. Alligevel anser han nordisk mytologis skildring af vendepunktet i kampen mellem godt og ondt for ubetalelig, for netop deri "vorder Nordens Mythologie i sin Hjemstavn en velkommen, bestemt og for saavidt uundværlig Symbolik eller Form for den egenlige historiske Poesie, den kan ingenlunde oplive Historien, men kan dog som en Ahnelse bidrage til dens Opstandelse og som dens Forbillede tjene den til Betegnelse« (8r).

De фvrige udkast er lidt yngre. 1823 var året, hvor Grundtvig endelig fuldførte Saxo-Snorro-oversættelsen med udsendelsen af de to bind III. I en efterskrift offentliggjort i Nyeste Skilderie af Kjøbenhavn 9. august 1823 betoner Grundtvig endnu en gang, at Norden har 
»en Mythologie, som universalhistorisk omfatter og afbilder hele Helte-Livet i hele Menneske-Slægten«, med tilføjelsen: »og en OldHistorie, der mythisk udfolder dette Liv i nordisk Kæmpe-Daad « (US IV, s. 194).

En meget omhyggelig renskrift, Nordens Aand (Fasc. 254), efter papirtype fra tidsrummet marts-oktober 1823 , analyserer systematisk titelbegrebet. Først definerer Grundtvig ånd som »noget Usynligt og Uhaandgribeligt « (1r), dernæst som »noget Virkeligt, om ellers det er virkeligt som virker « (1v), endelig som »noget Stort og Vaeldigt, om ellers det er stort, der kan oversee alt Andet, om ellers det er Vældigt, der kan overvinde al Modstand; thi det har Aanden i Troen beviist den kunde, det indrømme selv dens arrigste Fiender, og bygge netop derpaa deres Klage-Maal over den, som en afskyelig Misdæder og Krop-Forræder, som har bragt Millioner til at ringeagte ei blot de lækkreste Skilpadde-Gilder, men selv Guld og grønne Skove, ja al Verdens Herlighed, og som giennem Aartusinder har holdt de usle forblindede Kroppe, som Kiød-Pølser, i det skammeligste Fangenskab, uden at selv de stærkeste og forvovneste Kroppe, saasom Hunner, Avarer, Vandaler o.s.v. har mægtet at bryde de gruelige Lænker, men ere tvertimod begravede under dens Seiers-St $\varnothing t t e$ « (2r). Efter således at have bevist åndens eksistens spørger Grundtvig, om ånd skal elskes eller hades, underst $\varnothing t t e s$ eller bekæmpes, og anbefaler læseren at holde med den stærkeste part, altså netop ånden.

I næste afsnit definerer Grundtvig »Folke-Aand«: »en vis hos Folket herskende Aand, som virker en vis Betragtning af de synlige Ting og timelige Forhold, som er dette Folk eiendommeligt, og forsvarer sig med Kraft mod Hvad der bestrider den« (3v). Fremdeles systematisk spørger han: har Norden en sådan ånd, og i bekræftende fald, af hvad art er den da? Det første spørgsmål deler han atter i to: har Norden en ånd i dag, eller har Norden historisk betragtet en ånd, der har hersket her og ellers ingensteds? Svaret bliver et umiddelbart ja til det første, mens det sidste udløser en nærmere undersøgelse: »Naar man spørger om en Folke-Aand, da spørger man med det Samme om en Folke-Poesie; thi Poesie er Aandens uvilkaarlige og derfor nødvendige Yttring, og det Folk der ei har nogen eiendommelig Poesie, har heller ingen Aand, men hvor det Første findes, forudsætter Det nødvendig det Andet, som en Virkning sin Aarsag « (4r). Et blik på, om nordisk poesi virkelig er noget særegent nordisk, er fornødent: »Man har meent at kunne afvise Spørgsmaalet med den 
Paastand, at Nordens Poesie i al Fald er barbarisk, men deels er barbarisk et aldeles ubestemt Udtryk altsaa kun et Skiælds-Ord, og deels spørge vi ikke her om hvordan Nordens Aand vel er, men kun, om Norden har en Aand, den være nu barbarisk eller ikke. Har Nordens Poesie noget Eiendommeligt som forudsætter en egen Aand, det er da Spørgsmaalet, og her maa de trende Samlinger af nordiske Vers komme under Bedømmelse de angelsachsiske nemlig, de islandske og de danske« (4v-5r). Grundtvig påbegynder en udredning af, at versemål og metrik kun $i$ en del af de islandske vers er særlig for Norden, men finder dog $\gg$ i det Indvortes: i Indholdet saa meget Eiendommeligt, saa meget som intet andet Folk kan eller vil tilegne sig, at det unægtelig forudsætter en nordisk Aand. Først er nemlig National-Historien eller Nordens Oldsagn dens eneste Indhold, dernæst er Behandlingen hverken græsk, romersk eller ebraisk men dog aandelig, og endelig opdager man i Symboliken et eiendommeligt BilledSprog deels af mythologisk, deels af historisk, og deels af sympathetisk Oprindelse « (5r). På dette spændende sted, som nok kunne trænge til at blive udfoldet, slutter teksten nederst på siden - ufuldført. Den har måske været tænkt som en tidsskriftafhandling.

En mere konkret anledning ses i manuskriptet Om Nordens Oldsagn (Fasc. 256), efter papirtype placeret mellem juni 1823 og februar 1824. Den knytter sig nemlig til P.E. Müllers bog Kritisk Undersøgelse af Danmarks og Norges Sagnhistorie, 1823. For Grundtvig betegner både denne bog og Müllers Sagabibliothek, 1817-20, et godt skridt fremad for videnskaben. Müller trænger ikke til Grundtvigs anbefaling, for Grundtvig véd udmærket godt, at han »som en gammeldags Orthodox maa være hvad man kalder uhyre intolerant, og desuden, som en ikke ganske ubekiendt Polemiker, haardnakket og gienstridig « $(1 \mathrm{r}-\mathrm{v})$.

Grundtvig er tilfreds med Müllers større grad af upartiskhed i sammenligningen mellem Saxo og Snorre end hos de videnskabelige forgængere, således at oldhistorikeren og Saxo-udgiveren Stephan Stephanius' afbrudte gerning (fra 1640'rne) nu omsider genoptages. „Stephanius gik nemlig ud fra den, efter mine ringe Tanker, eneste rigtige Grundsætning, at man med Glæde og Taknemmelighed maatte modtage ethvert Bidrag de gamle islandske Bøger kunde yde til at forøge og oplyse de nordiske Oldsagn vi fandt hos Saxo, men at Islændernes Taushed paa ingen Maade gjorde Saxos Ord til Snak, og at deres Modsigelse maatte understøttes af forsvarlige Grunde, hvis 
Saxos Ja ei skulde være ligesaa godt som deres Nei« (1r-v). Grundtvig minder om, at Saxo faktisk levede midt i det 12. århundrede, mens næppe nogen islandsk bog er så gammel. Saxos oldsagn kan netop lægge et historisk grundlag for de nordiske myter, og det er derfor absurd at sætte de islandske og de danske kilder op imod hinanden, snarere skulle man slutte en evig fred imellem dem: »en oprigtig hellig Alliance til væbnet Forsvar af Nordens historiske Tro mod alle Tydskernes naturlige Angreb, af Skjoldunge-Thronen mod alle videnskabelige carbonariske Paafund « (3r).

Det var i tilbageblik islænderen Torfæus, som først brød en sådan fred med sine angreb på Saxos sagn (omkring 1700). Danmark takkede ovenikøbet herfor, Holberg lo ad oldsagerne, og først med Suhm ændredes billedet, dog tøvende og kun med kritik af de islandske kilder, islænderne selv anså for upålidelige.

»Saaledes var Stillingen i Slutningen af det Attende Aarhundrede, Saxo og med ham Danmarks Oldhistorie var saa godt som gandske opgivet, Gram havde i Noterne til Meursius, som vor udenlandske Minister, officel ${ }^{9}$ kundgjort det for alle Europas videnskabelige Magter, og naar Nogen spottede med Saxos Æventyr, gienmælede vi ivrig, der kunde Ingen dybere foragte dem, end vi selv. Tydskerne, som godt indsaae, at Nordens Mythologie og Oldsagn udgjorde et Heelt som maatte staae Last og Brast bekæmpede det Hele under Eet med samme Vaaben, men vi var føielige nok til at opgive vort Eget og forsvare Islændernes, ja ei blot deres virkelige Oldsagn, men ogsaa deres Urimeligheder og smagløse Paafund, hvilket man vel maa sige, var videnskabelig talt at kaste Dannebrog og kæmpe for den tørre Fisk « (4v). Grundtvig mener afsluttende, at selv islændere nu må betragte Torfæus' og Schønings behandling af Saxo og hans oldsagn »som en uforsvarlig Mishandling« (5r).

En variant af denne vurdering findes i Om Oldsagnene hos Saxo (Fasc. 267.2), med samme datering. Suhms valne forsvar for Saxo beskrives: »Islanderiet med hele sin storagtige Overtro og Smagløshed herskede dengang i nordisk Oldgrandskning, alt Islandsk var ypperligt, og selv de usleste Ammestue-Sager fra Island var i det Mindste rimeligere end hvad der kun havde sin Hjemmel hos Saxo« (1v).

Grundtvig ironiserer over sin egen plads i videnskaberne: »min Stemme skal i den lærde Verden være om ikke ganske Nul, dog saa omtrent. Som det gaaer hermed, gaaer det naturligviis ogsaa med 
mine Tanker om Oldsagnenes historiske Værd, jeg har meent, og tør endnu mene, at dette ingenlunde beroer paa hvorvidt man deraf kan udpille et enkelt Navn, som en Helt eller Høvding paa en vis bestemt Tid har baaret, en enkelt Bedrift som netop for saa og saa mange Aar siden, paa det og det Sted, under de og de Omstændigheder er $\emptyset$ vet; men at Hoved-Sagen er, om hvad man udgiver for Oldsagn ogsaa virkelig er det, thi i saa Fald har de, endog i deres største Vilderede ubetaleligt Værd, som paalidelige Mindes-Mærker af det Folks Aand og Hjerte og Bedrift, som de tilhøre« (2r). Teksten slutter $2 / 3$ nede på siden.

På samme tid planlægger Grundtvig en ny udgave af sin 1808håndbog i nordisk mytologi. To overvejelser herover er bevaret (Fasc. 251). Den første er en fragmentarisk redegørelse for de kristne boglærdes mulige pligt til »at tilintetgiøre alle hedenske Mindesmærker « (1r). Dernæst tager Grundtvig fat på en egentlig Fortale, der bliver hans udførligste tilbageblik på den nordiske renæssances historie $\mathrm{i}$ Danmark. Efter ganske kort omtale af de ældste kilder: frankiske skribenter på Karl den Stores tid, angelsaksiske slægtsregistre, Adam af Bremen, Saxo og de islandske skrifter fra middelalderen daterer han den moderne viden om nordisk mytologi til det 17. århundrede, altså 200 år tilbage. Han ridser i hast de lærdes interesse for sagen op fra Brynjulf Sveinson, Árni Magnússon, John Eriksen til Mallet, Suhm og Sandvig. Trods alle disse prisværdige bestræbelser manglede der dog respons både $\mathrm{i}$ den lærde og $\mathrm{i}$ den læge læserverden, konstaterer Grundtvig. Årsagen hertil finder han

deels i de Lærdes udelukkende Forkiærlighed for det græske og romerske Afguderie, forbundet med græsk og romersk Fordom mod andre Hedning-Folk som var Barbarer, deels, hvad Norden angik i den gamle Vane, kun at tilstaae de Studier Borger-Ret i den lærde Verden, som havde faaet Brev derpaa i Tydskland, hvor Sædet var for Borgemester og Raad. Med dette Borgerbrev havde det imidlertid sine store Vanskeligheder, især fordi Borgemester og Raad derude hverken kunde Dansk eller Islandsk, og stod desuden i den vrange Formening, at der ei i Danmark eller paa Island kunde findes Noget som fortjende at oversættes paa Tydsk eller Latin. Naturligt var det ogsaa, at tydske Lærde, der ei som de Nordiske, fandt Mythologien indvævet i deres Fædernelands Old-Historie, maatte, for at 
erkiende dens Værd, hæve sig til en almindelig poetisk Betragtning af Gienstanden, thi ogsaa kun ved en saadan Betragtning kunde Nordens eventyrlige Old-Historie faae Værd i deres Øine. Virkelig gav ogsaa Herder den paa en saadan poetisk Grund Borger-Ret, ved med Berømmelse at optage Völuspa imellem sine Folke-Stemmer, som en prophetisk Røst fra Norden; men han var i de Lærdes Raad ene om denne Mening, som om Synet hvoraf den udsprang, og hans Dom agtedes da for en licentia poetica, der Ingen bandt, end ei ham selv, som Lærd betragtet.

Da imidlertid Suhms skrifter såvel som det arnamagnæanske bind I af (ældre) Edda krævede et svar, affattede de to lærde historikere A.L. Schlözer og J.C. Adelung »en formelig Nægtelse af al Borgerret i det hellige Romerske Rige til hvad de kaldte en Hore-Unge af en gammel Munke-Hjerne og Kiærlinge-Sladder i en islandsk Amme-Stue « (4r). Her stod da sagen i Grundtvigs barndom, hvor de nordiske forskere syntes at ville glemme mytologien igen, så »naar Skule Thorlacius og Rasmus Nyerup var samlede til deres Fædre Magnæus og Eriksen, Bartholin og Suhm, vilde det omtrent være forbi med Lærdes Taler om Nordens Myther« (4r-v).

Kun en femtedel inde i det nye århundrede kan Grundtvig imidlertid se en interesse for nordisk mytologi, som ikke bare fortsætter den gamle $\mathrm{i}$ »en Efterklang af Tonen, som ei med Eet kunde uddøe«, men virkelig er »nyvaagnet «. Det skyldes, mener han, at »den større danske Læse-Verden « denne gang er kommet med, så den forudsigelse, der omkring 1800 ville have været urimelig - at »om ti eller tyve Aar skal Nordens Mythologie være bekiendt og temmelig almindelig yndet mellem danske Læsere « (4v) - i dag er sand. Denne udvikling er ikke hidført af det 18. århundredes mænd Suhm og Sandvig,

thi hvem vilde vel i den kiedsommelige Bog om Odin [af Suhm 1771] søge de mange Oplysninger, som var nødvendige for blot nogenlunde at forstaae de eddiske Sange hos Sandvig, der ovenikiøbet kun saae ud som Vers, og havde for de Fleste intet Tillokkende. Hvad skulde der fremdeles komme ud af hvad man tilraadede og stundum fulgde, at sætte Odin for Jupiter, Brage for Apollo, Freia for Venus og Valhal for Elysium i 
Vers, hvad andet, end at de fleste Læsere ærgrede dem over at skulle lære et nyt mythologisk Alphabet istedenfor det giængse, uden at kunne indsee mindste Grund dertil.

En sådan grund leverede Oehlenschläger, der teoretisk i prisafhandlingen, praktisk i sine ungdomsbøger beviste, at den nordiske mytologi var passende for digterne at $\emptyset$ ve deres »Skabe-Kraft « på:

I Vaulunders Saga saae man en af Eddas Sange opstige af Saga-Havet som en liflig Morgen-Røde, der forkyndte en ny Skabe-Dag, forkyndte Gienfødelsen af den oldnordiske Literatur til videre Uddannelse; thi den lille mishandlede Guldsmed fra Nordens Bjerge, viiste efterat have tugtet sine Bødler, at han var en Valkyrie-Mand, som naar Benene blev lamme, kunde hæve sig i Fjeder-Hammen og lee ad hele Verden.

Det Syn saae ogsaa jeg, og det slog mig, der kom Liv i den Drift jeg fra Barnsbeen havde havt til at sysle med det gamle Norden, der kom Lys i min blinde Kiærlighed til Nordens Myther og Oldkvad, begeistret saae jeg i Aanden Mytherne opstaae forklarede som et nordisk Stjerne-Billede der ei blot kastede Lys paa det hele nordiske Kæmpe-Liv, men havde i Forening dermed en høi og herlig Betydning for hele Menneske-Slægten.

Grundtvig finder i Oehlenschlägers Nordiske Digte, 1807, med Thors Reise, Baldur hin Gode og Hakon Jarl hin Rige, en tilstrækkelig parallel til de antikke digte, som har sikret klassisk mytologi gennemslagskraft:

Betragte vi disse Digte ved Siden af de romerske og græske, da udgiøre de aabenbar en Literatur, som hvor indskrænket den er, dog kræver mythologisk Kundskab hos sine Læsere, og vil findes den Umage værd, det kan koste at forstaae dem, saalænge Danmark har poetiske Læsere. 
Grundtvig må dog gøre indvending imod Oehlenschlägers digteriske gengivelser:

De anspore imidlertid ikke til mythologisk Studium, da Digteren har taget sig den Frihed at giøre med Mytherne hvad han fandt for godt, og saa at sige brugt dem som Materialier til en ny Mythologie, der maatte læres af hans Digte, og havde kun i deres ei i det gamle Nordens Historie sin Betydning, og sit Grundlag.

Derfor - og her bliver teksten mere indirekte og antydende - er der stadig behov for, at Grundtvigs for længst udsolgte ungdomsværk om Nordens mytologi fra 1808 genudsendes. Ganske vist har Finn Magnussen netop afsluttet sin Edda-oversættelse (I-IV, 1821-23) og agter at fortsætte i en fremstilling af eddalæren (som kom 1824-26). Spørger nogen Grundtvig,

hvi jeg atter vil befatte mig med en Gienstand, der aabenbar for længe siden har holdt op at være mig en Hovedsag? Mit egenlige Svar er Bogen selv, og hvem det ikke tilfredstiller, har jeg derom intet at sige, men foreløbig maae jeg dog bemærke, at erkiender jeg mit første Skridt paa denne Bane for hensigtsmæssigt, da maae jeg nødvendig giøre det andet, eller rettere det tredie; thi det andet har jeg egenlig gjort ved at fordanske Saxo og Snorro.

Grundtvig er overbevist om, "at Nordens Mythologie fortjener vor Betragtning baade som et poetisk Storværk, og som et uundværligt Hjelpe-Middel til at forstaae Nordens Historie baade fordums og nu « (8v) - men her ender fortalen nederst på siden.

Projektet blev ikke til noget. Fra ca. 1824 stammer en Indbydelse til Pranumeration paa Nordens Historie (Fasc. 230.4), hvorefter Grundtvig i stedet har besluttet at skrive en letlæselig Nordens historie for voksne og dannede læsere ud fra de mange undersøgelser, han måtte foretage i forbindelse med oversættelserne af Saxo og Snorre, men ikke kunne placere i disse værker for »Børn og Menig-Mand « (2). En udtalelse om impulsen til oversættelserne kan supplere den 
eneste hidtil trykte om en Saxo-rus i januar 1815 (jf. fortalen til Saxo, I, 1818, US IV, s. 96):

En stærkere Følelse end jeg kunde modstaae, og dybere, end jeg har lært at lodde, var det som bestemde mig til at begynde fra denne Side, der ellers var langt fra at være den mest tiltrækkende for en saa magelig Skribent som jeg; men at jeg derfor ligefuldt havde Lyst til, paa en friere og mere behagelig Maade at bidrage til Oplivelsen af de forsvundne Dages Minde, følger af sig selv [..]

Dernæst kommer en hentydning til, at han arbejder på en fortsættelse af Saxo (3). Det havde Grundtvig røbet offentligt i et indlæg i Nyeste Skilderie af Kjфbenhavn 9. august 1823 (US IV, s. 190-195).

Ellers er det interessanteste Grundtvigs redegørelse for sit (mis)forhold til de lærde:

At jeg, efter fattig Leilighed, troer mig, med Guds Hjelp, det Arbeide voxen, jeg tilbyder, beviser vist nok ikke, at jeg virkelig er det, men det kan heller Intet bevise, uden Værket selv, det seer man især, af de mange ypperlige Danmarks Historier efter Saxos Tid, man paa de allergyldigste Grunde har ventet, men ikke faaet, og hvem kan vide det, maaskee kan man nu slumpe til en temmelig god, hvor man, efter lærde Folks Tanker kun har Ret til at vente en meget maadelig: ucritisk, plat og plump, eensidig, bigot og polemisk. Ret i Fortroelighed vil jeg nemlig bede alle Danske Læsere bestandig godt at regne Hælvten fra, naar ordenlig grundlærde Folk og jeg tale Ondt om hverandre, thi i dette Stykke er virkelig Ingen af os at troe meer end høist paa det Halve [..]

Selvbevidst og afslappet på én gang placerer Grundtvig sig i den samtidige videnskabelige verden:

Jeg er nemlig hvad man paa de Lærdes Sprog kalder Autodidact, det vil sige, jeg har gaaet min egen Vei og seilet min egen $S \varnothing e$, og troer jeg end derved at have vundet nogle af de 
Fortrin, der pleie kun derved at erholdes, kan jeg dog aldrig troe mig fri for de Mangler og Lyder som gierne klæbe ved alle saadanne Frimestere. Naar man nemlig saaledes gaaer sit Skud markesleds over, uden at bryde sig om Vei eller Stie, da seer og finder man naturligviis meget som der paa Landeveien deels kun skimtes, deels ei engang drømmes om, og fristes derved lettelig til at oversee eller skose dem der, uden at vige et Skridt til Høire eller Venstre, vandre trolig i hinandens Spor, ligesom det næsten er disse Folk med afmaalte Skridt, umueligt at lade os Landløbere vederfares Ret, ja, de indbilde sig let, at vor Vankundighed om mange Ting, som ligge lige for deres Øine, berettiger dem til at ansee og udraabe os for uvidende og keitede Fuskere. Begge Dele er imidlertid lige uretfærdige, og maaskee lige skadelige for sand Videnskabelighed, thi var der intet Laug, blev vist nok alting Fuskerie, men var der ingen Frimestere, da blev det lærde Væsen til et dødt og stillestaaende Handværk, var der ingen fast Stok af lærde Folk, af Linie-Tropper og ordenlige Poster, da gik det, som i Middel-Alderen, at alt Aandeligt stod enkelt, at alt Skinnende var som Nordlys, der kom og svandt, at det Erobrede kunde ikke forsvares, Handel og Vandel ei trives, og Forvirring aldrig forebygges; fattes man derimod os, der er at ligne ved lette Tropper til Hest og til Fods, ved Extra-Poster, Speidere og deslige, da sov man ind, kom aldrig videre, tyggede Drøv paa det Gamle, gjorde ingen ny Erobringer, lod alle Fæstninger forfalde, snakkede hinanden efter Munden, og forgik i lutter Pedanterie, Formaliteter og Guarnisons-Tjeneste;

Her standser manuskriptet - efter et overstreget afsnit - nederst på siden. I et beslægtet fragment uden titel (Fasc. 230.5) opstiller han et mere konkret program for en Nordens historie. Han vil inkludere oldsagnene fra sit vante bevidsthedshistoriske stade,

om de aldrig indeholdt meer Historisk, end hvad de unægtelig selv udgiøre: et usvigeligt Vidnesbyrd om, hvilke Forestillinger vore Fædre for et tusind Aar siden gjorde sig om Nordens Fortid, og hvad der i deres Øine var Stort og Elskeligt, Mærkværdigt og Poetisk, saa er dette allerede saa meget, at ethvert 
andet europæisk Folk vist maatte ønske sin Historie en saa larerig Baggrund! Uagtet jeg derfor neppe barer mig for at indstrøe enkelte Vink om, hvad jeg seer i visse Sagn, udgiver jeg det kun for løse Giætninger, og har kun den Oplysning i Sigte, som adskiller virkelige Oldsagn, fra enkelte Snakkeres flaue Æventyr.

En summarisk indholdsoversigt rækker fra Odin til Frederik VI! Men heller ikke denne bog bliver til noget.

Næste - og i denne runde sidste - initiativ er et manuskript til en Nordens Krønike til Skole-Brug (Fasc. 231), sandsynligvis fra 1824 eller $1825 .^{10}$ Norden defineres indledende ud fra det danske tungemål som Danmark, Norge, Sverige samt England mellem den angliske og normanniske indvandring (3). „Ved det gamle Norden forstaae vi egenlig Nordens Hedenskab, eller Troen, Tilstanden og Bedrifterne i Norden, førend Christendommens Indførelse, thi hermed begynder et nyt Liv, hvori den nordiske Natur er enten det Undertrykte, det Eftergivende, eller det Stridige, men ikke længer aabenbar det Herskende« (3-4). Begrundelsen for et studium af oldsagn og hedenskab bliver kristen:

Dette, at skiøndt Christendommen bandlyser og stræber at udrydde alt Hedenskab, bliver man dog Christen som man har været Hedning, og at selv den foregaaende Forvandling ligesaalidt hos et Folk som hos et enkelt Menneske, er et Øiebliks Sag, men udkræver et heelt nyt Levnets-L $\emptyset$, Det er, hvad der maa giøre os Kundskab om Nordens Oldtid vigtig og ønskelig, om aldrig for andet, saa dog for at kunne desbedre forstaae det christnede Nordens Historie, og lære i os selv at opdage, bestride og udrydde Hedenskabets Levninger.

Et folks hedenskab, fortsætter Grundtvig, røber nemlig dets sande hjertelag:

Derfor maatte et Christen-Folk, selv naar det stod ved Maalet, og ei længere til Lærdom, Tugt og Advarsel, behøvede at mindes sit Hedenskab, dog altid betragte det, som vi engang $\mathrm{i}$ 
Evigheden vil betragte vor jordiske Bane, under levende Ihukommelse af Alt hvad der paa den omringede og rørde os, som Billeder og Skygger af det Himmelske og Evige, hvortil vi stundede.

Efter en henvisning til Paulus' Areopagos-tale (Ap.G. 17.28) standser udkastet midt i en sætning. Grundtvig har dog også skrevet et indledningskapitel, Første Tidsrum til Gorm den Gamle, Harald Haarfager, og Erik Seiersal - igen med et forsvar for en kristens fascination af hedenske oldsagn:

\begin{abstract}
Alle Mythologier forudsætte hvad Bibelen lærer, at Mennesket er skabt i Guds Billede, uden hvilken Forudsætning, der slet ikke lader sig nogen sand eller falsk Guds-Kundskab tænke; thi vi kan umuelig forestille os det Ubekiendte uden under Billedet af noget Bekiendt, umuelig forestille os [den] usynlige Skaber uden under vort eget Billede. Deres høieste Tanker og kiæreste Ønsker var det nødvendig Hedningerne forgudede, og historiske daadfulde og mindekiære Folk maatte da ogsaa skabe sig en historisk Mythologie, tænke sig Guderne, som deres Skabere, der besad deres Tænkemaade, nærede deres Ønsker i høieste Grad, og havde den størst muelige Kraft til seierrig Virksomhed efter Hjertens Lyst.
\end{abstract}

Myter ligner de mest historisk lydende sagn, fortsætter Grundtvig: »Ligheden er nødvendig, da Mythologien og Historien afbilder et og det samme Menneskeliv, hin dets aandelige og denne dets legemlige Side, der nødvendig maa svare til hinanden, og være saa lige, som Legemet er Aanden som Handlingen er Tanken, og det giælder da her ei om at finde Ligheden men Forskiellen; thi det giælder om at adskille hvad Folkene i deres Oldsagn nødvendig stræbde at forbinde « (9-10). Herefter opstiller Grundtvig en af sine yndede tredelte oversigter over stoffet, fulgt af overvejelser over forholdet mellem Saxo, islænderne og Beowulf som kilder. Afsnit om regulær Danmarkshistorie når kun til de tidligste sagnkonger, således kong Skjold, hvor Grundtvig fører sin nye viden (fra suppleringen af Beowulf med engelske middelalderkrøniker) frem: 
man har det deilige Sagn, at han i sin spæde Barndom kom ene drivende til Danmark paa et Skib, ladet med Vaaben, hvor han fandtes slumrende paa en Korn-Neg, ret som man kan forestille sig en livsalig Drot, født til at herske ved Kiærlighed i KornVangen, kun væbnet for at frede den, og da alle Sagn stadfæste, at han var saadan Folke-Ven og Lande-Værge, er det intet Under, at Dannemark vil have alle sine Konger af hans Æt; men vel er det et besynderligt Held at Saamange af dem har sat en Ære i at ligne ham.

Ingen af de grundige overvejelser 1821-25 leder således til nogen konkret udgivelse.

\section{Stilhed og nye fremstфd}

Som mytologisk forsker og formidler ligger Grundtvig underdrejet i årene 1824-31. Et afgørende nybrud kommer som så ofte beskrevet med Nordens Mythologi eller Sindbilled-Sprog historisk-poetisk udviklet og oplyst, 1832 . I den lange indledning søger han at se myterne som et universelt billedsprog. Derfor kan han iværksætte en kraftig opvurdering af Snorre. Hvor den yngre Edda i $1808 \mathrm{blev}$ hængt ud som en sen, usammenhængende og kristelig kilde, kalder han den $\mathrm{i}$ 1832 for »en egen Mythologie, og en Æsthetik hvori alle Exemplerne er taget af Classikere paa Moders-Maalet «, noget, som i middelalderen er uhørt uden for Norden. Snorres fortale anser Grundtvig nu for »Noget af det mest Genialske, der er skrevet om Myther (..) den historisk-poetiske Anskuelse af Billed-Sprogets og Hedenskabets naturlige Oprindelse, som maa gaae forud for en videnskabelig Mythologi og Æsthetik« (US V, s. 493 og 497). Selv de tilsyneladende latterlige historiserende navneidentifikationer i fortalen røber »det skarpe Blik«, der opfatter asalivet som »hvad det er: det forgudede Helte-Liv« og udleder myterne i det hele fra »Navne-Vexelen ved Tunge-Maalenes Blanding, og fra det faldne Menneskes poetiske Natur-Anskuelse «. Efter Grundtvigs mening var »den gamle Nordiske Klerk [..] med al sin Troskyldighed (Naivitet), langt grundigere Mytholog end de Høilærde, der beloe hans Vankundighed « (s. 495). Som poetik - lærebog i digtekunst - finder Grundtvig Snorres Edda lidt kedsommelig i lighed med andre bøger i genren, især i de sidste, 
mere teknisk orienterede dele, »men at det var lagt an paa noget anderledes Dybt, skal vi glæde os over, og ingenlunde mistvivle om, videnskabelig at forbinde Skiønhed og Klarhed, som er Poesiens Krone, med Aanden og Livet, som er Hoved-Sagen, Sjælen og Hjertet deri« (s. 497). Mytologien skal i det hele taget bruges $i$ handling snarere end forstås, fordi myterne netop taler anskueligt om usynlige åndelige fænomener. Blandt de talstærke utrykte forarbejder til bogen kan et fragment fremhæves, hvor Grundtvig tager stilling til det 19. århundredes berømteste oldtidsgendigtning, Esaias Tegnérs Frithiofs Saga, 1825: „Den Benyttelse Tegnér i sin Frithiof har gjort af Havamaal turde saaledes være det mest Poetiske i hans yndede Værk, som aldeles fattes den skjaldelige Anskuelse, og ophøier den spidsborgerlige Miskiendelse af Nordens Billed-Sprog « (Fasc. 272,XIV 76v).

Endelig er der i forhold til 1808 sket et vigtigt stilskifte. Hvor Grundtvig dengang skrev højpatetisk eller skærende hånligt om fortællingerne, anlægger han nu generelt en lunefyldt, humoristisk stil, lagt mere over ad det mundtligt causerende. Et andet forarbejde siger herom: læseren skal ikke have »en tør, kiedsommelig Opskrift paa Udgaver, Navne og Aars-Tal, men kun en levende, mundtlig Fremstilling, som ikke staaer i Pennens Magt, og som vilde være endnu mere nødvendig til frugtbar at udvikle de væsenlige Tjenester vore Fæderne-Myther baade kan og skal giøre os under det store Uddannelses og Oplysnings Værk, som er vor beskikkede Deel« (Fasc. 274,II 27v).

I sin Haandbog $i$ Verdens-Historien, II, 1836, hylder Grundtvig det gamle Island for at have dyrket det virkelige liv og ikke gloser, gætninger, bøger og snurrepiberier, for at have brugt modersmålet og for at have tilladt ordets frihed. Grundtvig er jo her efter enevældens sidste revision af trykkefrihedsloven (1834-35) ved at lancere sine kampskrifter for en central folkehøjskole i Sorø. Snorre betegnes kort som mere samler af end forfatter til Heimskringla, og tilsvarende anser Grundtvig mindre end nogensinde de mytiske oldsagn i Edda for hans værk - snarere er de oversat fra angelsaksisk og omsat i islandsk versekunst (US VII, s. 143-146).

Mands Minde-foredragene på Borchs Kollegium i sidste halvår af 1838 indeholder en påstand om, at når det synes, som om »Nordens Billed-Sprog er langt nærmere ved at $\mathrm{d} \varnothing$ ud i mig end at leve op i andre « (Mands Minde, 1877, s. 456), er det en illusion, fordi England 
jo slog Napoleon, så der mangler blot, at England erkender sin ånd i nordisk billedsprog og Norden genkender sin ånd i engelsk liv.

I den lange artikel Om Nordens videnskabelige Forening i tidsskriftet Brage og Idun, 1839, gør Grundtvig Heimdall-myten til forvarsel for sin tanke om én videnskabelig højskole for Norden - »en Anelse, den Nordiske Kæmpeaand i sin fyrige Ungdom havde af sin besindige Alderdom [..] Lys-Nøglen til hele Nordens Billed-Sprog « (Grundtvigs Skoleverden, II, 1968, s. 163).

Op mod 1840 nærmer Grundtvig sig atter mytologien, skønt han ikke har held med den i sin folkeoplysende forening Danske Samfund 1839-43. Et manuskript fra denne tid skal nævnes: Nordens Myther og Oldsagn for Damer og Herrer (Fasc. 285), der i et indskud om Ciceros dødsdag anfører 7. december 1839 som en fremtidig dato (6r). Det er ejendommeligt af to grunde. For det første, fordi det har hele den sluddervorne og maniske optagethed af de tilstedeværende damer, man ellers først forbinder med Brage-Snak-foredragene fire år senere, for det andet, fordi den aktuelle anledning og dermed tilhørernes art er ukendt. Datoen 7. december faldt i 1839 på en lørdag, men arrangementet kan være blevet aflyst, fordi Frederik VI var død den forudgående tirsdag. Det saglige indhold af den lange forelæsning er beskedent. Grundtvig umager sig især med "ganske alvorlig at forsikkre, at det hverken er min Hensigt at indføre det Nordiske Hedenskab igien, med St $\varnothing$ tterne i Lunden, og med Giæstebudene paa Hestekiød for Guder og Mennesker, endsige da med de grusomme Menneske-Offere, Man ikke kan nægte, engang fandt Sted i Sverrig og Norge, og som Tydskerne vil beskylde os Danskere for at have drevet til det Yderste, skiøndt Blodtørst dog ellers ikke er hvad Man beskylder os og Danerne for « (5r). Hans grund til at tage fat på myterne er simpelt hen, at han finder dem »i sig selv smukke, vittige, poetiske og, menneskelig talt, uskyldige i alt det Afguderi, der har været drevet og kan drives med dem« (5v). De skal netop tilegnes poetisk, "fordi nu disse Oldsagn umuelig kan holde Stik, naar Man tager lige efter Bogstaven og Hverdagslivets Regler hvad aabenbar er skabt i Munden til en Høitid og beregnet paa levende og vittige Tilhørere og Tilhørerinder, som forstod en halvkvæden Vise og var hjemme i Billedsproget « (6v).

De faktisk afholdte offentlige foredrag - for damer og herrer - over græsk og nordisk mytologi på Borchs Kollegium vinteren 1843-44 resulterer i bogen Brage-Snak fra sidstnævnte år. Her karakteriserer 
Grundtvig i forbigående Snorres Edda som »meget mere poetisk end de fleste 'Samlede Digte' nuomstunder « (US VIII, s. 529). Grundtvig drømmer om en fortsættelse af en oldnordisk inspireret moderne digtning: de unge mænd bør læse Vaulundurs Saga og Hakon Jarl af Oehlenschläger - den genkomne digtergud Brage - højt for damerne, indtil der blandt dem findes »Een til at fortsætte det Valhalliske Harpeslag, hvormed Nordens Ære staaer og falder« (s. 577). Et pant på »Folke-Aandens Seier og Kæmpe-Livets Udødelighed i Norden« (s. 597) har man i de hedenske navne på nogle af ugedagene, hvor Thor, Tyr og Odin på dansk og engelsk »lever endnu, om end lidt forklædt og forklemt« (s. 607).

I Brage-Snak - dette overflødighedshorn af Grundtvigske billeder og associationer - er hans forkyndelse af det levende ords fortrin også vendt imod hans egne oversættelser af Saxo, Snorre og Beowulf, som byggede på »den latterlige Indbildning, at naar man kun har Aandens og Hjertets Skatte ordenlig ført til Bogs, ynder Beskrivelsen og lærer den udenad, da bliver man hovedrig i et Øieblik, ligesom de, der vinder den store Lodd i Lotteriet « (s. 743). Troen herpå var forkert. Med hentydning til Homers digteriske beskrivelse af den hjemvendte Odysseus' greb om sin gammelkendte bue - emnet for forrige kapitel - trøster Grundtvig sig nu:

hvad Bøger ikke mægter, det mægter dog endnu det mundtlige Ord, mægter baade selv at oplives af Aanden og at virke med Dens Kraft paa alle beslægtede Naturer, saa naar vi kun lære ret at spænde 'Kæmpe-Buen', da giør den nu som fordum sin Pligt, og aabenbarer alle sine gamle Dyder.

Imidlertid fremsatte den klassiske filolog, professor J.N. Madvig i Om Skandinavismens Forhold til den almindelige Cultur. Et Foredrag, holdt $i$ det Skandinaviske Selskab den $27^{\text {de }}$ Januar 1844 nogle nøgterne indvendinger imod nordisk mytologi både som et rigt og dybt idéindhold og som en fantasiæggende inspiration for kunst. Madvig fastslår, at nordisk mytologi som filosofi ikke kan besvare spørgsmål, der ikke kunne stilles i oldtiden. Han konkluderer på sit indviklede dansk, at mytologien har »kun i sine rene Antydninger af Gemyttets Trang og Indhold Incitamentets, i sine bestemte Skikkelser det vederqvægende og kraftigt tiltalende Ideals Ret og Betydning« 
(særtryk s. 15). Madvig er også skeptisk over for den sparsomme og sene (kristne) overlevering af nordisk mytologi over for den velhjemlede græske hedenskab. Som inspiration for kunst er nordiske myter ligeledes problematiske, eftersom de - modsat de græske - ikke formedes $\mathrm{i}$ bildende kunst, dengang folk troede på dem. I $\emptyset$ vrigt synes han, at moderne danske kunstnere, trods alle opfordringer til at skabe en ægte national kunst, med rette er mindre ivrige for myterne, for vor nationalitet har jo i tusind år været kristelig (s. 18-19). Samme skæbne har ramt antik mytologi. Hos Thorvaldsen er de græske guder, afklædt for deres oprindelige hellighed, blevet almindelige symboler med »et Efterliv, der ikke blot beroer paa boglig Lærdom« - de er således i hans bas reliefs »reent humane Symboler for Aandens og Gemyttets Verden« (s. 19-20). Også Oehlenschläger har i Nordens Guder, 1819, indsat mangt et »subjectivt moderne Træk i Opfattelsen og Fremstillingen« (s. 21). Madvig giver afsluttende udtryk for sin overbevisning om, at kunstnerisk behandling af nordisk mytologi aldrig vil overskride »det smukke, det opklarende Experiments, det isolerede Værks Standpunkt, medens Kunsten under Experimentet væsentlig støtter sig paa de i en anden Mythologies Tjeneste udviklede Former« (s. 21). Disse ord udtaler Madvig frit, siger han, med blikket fæstet på H.W. Bissens smukke bronzevalkyrie med drikkehornet, et receptionsstykke fra 1834-35, der unægtelig har stor lighed med både Thorvaldsens to versioner af Hebe og hans Ganymedes. ${ }^{11}$

I midten af 1840 'rne tog Grundtvig mere og mere del i det politiske liv. Hans tale Om Nordens Historiske Forhold i Det skandinaviske Selskab 20. oktober 1843 beklager savnet af »en Haandbog for Aanden i Nordens Historie, som jeg kunde forudsætte, var bekiendt, kunde laane af, og kunde henvise til« (US VIII, s. 480, jf. 483). Hans store tale på Skamlingsbankestævnet 4. juli 1844 kunne nok trænge til oplysende kommentarer fra en sådan bog.

Skolebogen Grask og Nordisk Mythologi for Ungdommen, et bestillingsarbejde til forlæggeren H.J. Bing, udsendt julen 1846 (trykår 1847), præsenterer for sidste gang samlet Grundtvigs holdning til brugen af nordisk mytologi. I sit forord begrunder han glad bogens tilblivelse:

Tænkte jeg nemlig, som vel endnu de Fleste, at Mythologi og Afguderi var hip som hap, og at Mytherne ei havde andet at 
betyde end hvad vi Allesammen veed og kan udtrykke langt kortere og klarere, saa man skal kun lære Mythologi for at vide, hvad det er Digterne spiller paa og de andre Konstnere har villet afbilde, da spildte jeg naturligviis ikke Tid og Flid paa nogensomhelst mythologisk Fremstilling. Nu derimod, da jeg veed, at alle agte Myther er de tilsvarende Folke-Aanders LivUdtryk, saa Grakers og Nordboers Mythologi har netop ligesaameget at betyde, som de har selv, i hele deres Levnetsløb, og at den staaer væsenlig i samme Forhold til det grove $A f$ guderi, som den oprindelige Christendom staaer til Billeddyrkelsen og alt Papisteriet, nu maa jeg ansee det for et af Folkelivets store Anliggender, at Ungdommen igien bliver bekiendt med sine Fadres og Franders Myther, og skal jeg fremstille dem, maa det være i den agteste Skikkelse, jeg kiender.

(s. V-VI)

Grundtvig afviser, at et moderne nordisk-mytologisk billedsprog blot skulle gå ud på at omskrive nogle simple og velkendte erfaringer. Men han er desværre ikke i stand til at give en klar redegørelse for, hvad den historisk betingede, ubrydelige enhed af indhold og form i et folks myter så nærmere karakteriseres af og kan magte. Det er igen den romantiske æstetiks forkærlighed for det uudsigelige og usagte som udtryk for det dybeste og sandeste.

Grundtvig indrømmer inde $\mathrm{i}$ bogen, at nordisk mytologi er sildefødt i forhold til græsk, så aserne passende kan ses »som Guder paa anden Haand «, og tilføjer: »Dette er ogsaa, heel mærkelig, Grundtanken baade i den løierlige Fortale og den latterlige Efterskrift til Gylfelegen «. Odin og Thor gøres her til Priamus og Hektor, Trojas $\varnothing$ delæggelse til Ragnarok, »hvad vel er pudsigt og plumpt nok, men viser dog, at man tidlig opdagede det verdenshistoriske Præg, der er Nordens Mythologi eiendommeligt «. Han må også indrømme asernes mangel på fast og plastisk karakter:

Selv at faae Tal paa Nordens Guder falder vanskeligt, omtrent som at giøre Mandtal i en Leir, hvor der ikke blot daglig fødes og døer en heel Deel, men hvor altid Somme, der har indlagt sig et Navn, sporløs forsvinder, medens Andre, man veed tit ikke hvorfra, pludselig springer frem og giør sig navnkundige. 
Bogen er illustreret af den ikke videre fremragende kunstner D. Jacobsen (1821-71), hvis nordiske figurer ligger tæt op ad de publicerede tegninger af J. Th. Lundbye, L. Frölich og P.C. Skovgaard fra Den Nordiske Høitid 1845 - for nu at sige det høfligt. Tegningerne er godkendt af Grundtvig. Bogen blev aldrig trykt op.

Lige før Treårskrigen, $i$ årsskiftet 1847-48, planlægger Grundtvig en nyoversættelse af Snorres Edda (Fasc. 390.2). Han vakler mellem titlerne Snorros Edda til Hverdags-Brug og Edda-Bogen om Nordens Billedsprog - bestemmer sig endeligt for den første. Et indledningsdigt handler om de hedenske ugedagsnavne (tirsdag, onsdag, torsdag og fredag). Han beklager, at dagenes navne ikke siger samtiden noget, priser trods alt den skriftlige overlevering og tror på, at en moderne skjald, som er inspireret, vil kunne opgrave asernes lig igen og blæse liv i dem. Da projektet aldrig udføres, trykkes dette digt i stedet i første nummer af hans tidsskrift Danskeren 22. marts 1848. Væsentlig er i strofe 4 Grundtvigs historisk-poetiske skelnen mellem hedensk kult og hedensk åndsliv:

Afgude-Vrimlen,

Steenstøtte-Himlen,

Fik paa vor Slette

Løn som forskyldt,

Men med Urette

Dog Asernes Tylt,

Med Aand og med Ord,

Sank døde til Jord,

For de var Sangfugle i Norden!

To stort set enslydende Forord til denne fordanskning af Snorre, hver på otte sider, er bevaret (Fasc. 390.3 og 4). I det første udkast afviser Grundtvig det selvrosende afsnit $\mathrm{i}$ den Resenske 1665-udgaves version af Snorres fortale, men ytrer et lyst håb om det nordiske billedsprogs fremtid:

Vist nok er det en latterlig Overdrivelse, naar samme Bog udgives for et saadant hexemæssigt Kilde-Skrift om Nordens Skjaldskab, at det baade kan gienføde det Gamle og immer føde Nyt; men saa galt har man læst om hvad der duede til 
ingen Verdens Ting, medens Edda virkelig har bidraget meer end der lader sig beregne til Gienfødelsen af Nordens eiendommelige Billed-Sprog og vil, naar Gienfødelsen lykkes, altid bidrage uberegnelig til dets videre Udvikling og endelige Forklaring.

For det er jo med den gamle bog, »livagtig, som Læseren fik et Bes $\varnothing \mathrm{g}$ af en Sagamand fra det Trettende Aarhundrede, og hørde Alt hvad man dengang vidste at fortælle og gad hørt om det gamle Nordens Aser og Asynier, Konster og Vidunder, og hele Fortællingen har en saadan Friskhed og saa at sige Mundsmag, som vi nuomstunder slet ikke kan give vore mythologiske Bøger « (7v). Eftersom Nyerups (og Rasks) fortræffelige danske og meget læselige oversættelse fra 1808, Edda eller Skandinavernes hedenske Gudelare, straks blev udsolgt og aldrig optrykt, vil Grundtvig nu påtage sig en tjeners skikkelse ${ }^{12}$ og fordanske bogen efter sit eget hoved, med tilføjelse af »den gamle, løierlige Fortale« og flere brudstykker af Skálda. Om oversættelsen bemærker han:

For Resten, saa uagtet jeg naturligviis oversætter saa nøiagtig, som jeg forstaaer og som jeg finder, Sprog-Forskiellen tillader, maa jeg dog bemærke, at $i$ en Bog, der slet ikke giøres til videnskabelig Drøftelse, men blot til Hverdagsbrug, er alt Prikkeri skadeligt, da det giør Stilen stiv og Læsningen besværlig, hvor Sagen netop er, at Alt kan løbe let og nydes med Lyst. De to jævne Sandheder, jeg herved har for Øie, er nemlig først den, at hvem der ikke er hjemme i sit eget Folks Billedsprog, er fremmed for hele Poesiens Verden, og at hvad man om Aandsting ikke hører eller læser med Lyst, er kun til Byrde og sløver istedenfor at vække og oplive, og vel har disse Sandheder længe været ubekiendte eller miskiendte i vore Skoler, men dels vil de i det Nittende Aarhundrede ventelig allevegne hævde deres Gyldighed, og i vort Norden, hvor ogsaa denne Bog viser, de alt for mange Aarhundreder siden slog dybe Rødder, maae de dog vel snart bære modne Frugter. 
Begge udkast slutter med den berømte eftermæle-strofe af Hávamál, »Deyr fé«, i meget forskellige enderimede oversættelser - ingen af dem gode.

Af oversættelsen får Grundtvig kun skrevet ti sider i forlængelse af sidste udkast til forord (Fasc. 390.4 11r-15v). Hans tekstforlæg er Snorra-Edda ásamt Skáldu, ved Rasmus Rask, Stockholm, 1818, den såkaldt de la Gardie'ske udgave. ${ }^{13}$ Med overspringelse af fortalen begynder Grundtvigs oversættelse forfra i Snorres Gylfaginning med Gefionmyten, Gylfes/Gangleris ankomst i hallen, og duellen på spørgsmål og svar vedrørende Alfader og verdens skabelse frem til Ymers død.

To træk er påfaldende. Grundtvig holder sig omhyggeligt klar af Nyerups 1808-tekst (der dog ikke indeholdt Gefionmyten), og stilen er så langt fra den arkaiserende tone i Grundtvigs ældre arbejder, at han bevidst undgår verbal overensstemmelse også, hvor den både er mulig og naturlig. For eksempel gengives »er nú heitir« (Rask, Gylfaginníng, 1818, s. 1) med »nuværende« (11r), »gaf« (s. 1) med »belønnede« (11r), »blótupu « (s. 2) med »dyrkede« (11v), »útrúligir« (s. 2) med »mistænkeligt« (12r), »hitt er mest« (s. 4) med »det Fornemste« (12v), »vândir menn« (s. 4) med »Tværdriverne« (13r), »loganda sverp« (s. 5) med »Flamme-Sværd « (13r), og »at kveldi« (s. 7) med »om Aftenen« (14v). En indlagt strofe af Bragi Skald (s. 1) oversættes til rent trokæiske, enderimede vers (11r-v).

En enkelt anden del af projektet dukker op i Danskeren for 9. juni 1849, en nyoversættelse af Eddas gamle Fortale. Under den tilsyneladende indslumrede Treårskrig vil Grundtvig trøste sig og læseren med "gamle Minder fra bedre Dage" (II, s. 337). Han vil gerne rehabilitere »den løierlige, men ingenlunde taabelige eller tankeløse Fortale « trods de lærdes ubehag ved dens bommerter imod bibelsk og romersk historie, fordi den netop giver en »naturlig, smuk og vittig Betragtning af Hedenskabets menneskelige Oprindelse og Beskaffenhed« (II, s. 339). Denne synsmåde har han lige forud udfoldet nærmere:

den nordiske mytologi udtrykker vore forfædres naturlige Betragtning af det Guddommelige, det Menneskelige og det Trollede eller det Uhyre, saaledes som disse Kræfter støder sammen og kæmper i Tidens Løb. Heraf seer vi nemlig, at vore æld- 
gamle hedenske Forfædre har været ved et frit Mod og havt et godt Haab, fordi det bares dem for, at det Guddommelige og det Menneskelige var dog igrunden af eens Art, saa de maatte tilsidst klarlig giøre eet og da tilintetgiøre alt det Trollede, saa det blev en Lyst at leve [..]

Grundtvig advarer imod at forveksle hedenskab og afguderi:

Hele den saakaldte Nordiske Mythologi er saaledes Hedenskab, som de nordiske Hedningers naturlige Tankegang og Billedsprog, men Afguderiet, Dyrkelsen af Odin, Thor og Frey og deres Billeder istedenfor den eneste usynlige Gud, Himmelens og Jordens Skaber, det var ligesaavel en aandløs Forvanskning af det oprindelige Hedenskab, som Helgen-Tilbedelsen og Billed-Dyrkelsen i Pavedømmet var og er en aandløs Forvanskning af den oprindelige Christendom. Derfor følde ogsaa vore Nordiske Fædre, da de først lærde at kiende Christendommen og den Bibelske Historie, at disse vel stred imod al AfgudsDyrkelse, men at de godt lod sig rime sammen med deres hedenske Forestillinger om Livets Kræfter, Kamp og Udvikling i Tidens Løb, saa de to Ting var som Alvor og Gammen, der altid i Norden kan godt sammen.

(s. 337-339)

Til næste uges nummer af Danskeren har Grundtvig fundet sit utrykte digt Nordens Guld fra 1834 frem, tilsat en aktuel efterskrift på rim, og i følgende uge besværer han sig over det danske folks søvn på krigsfod. Sejren ved Fredericia 6. juli skulle give ham andet at tænke på end en tillempning af Snorres Edda til hverdagsbrug. Projektet forsvinder uden yderligere spor.

Året efter, da den slesvig-holstenske krig i realiteten er ovre og vundet, er Grundtvig igen fremme med en mytologisk plan. I artiklen Nordens Mythologi i Danskeren 7. december 1850 reagerer han på en efterlysning fra publikum af et optryk af hans 1832-bog, denne gang med et navneregister. Han bliver ved hverdagsbrugen af bogen, da han fastslår, at få har godt af at læse meget om Nordens guder, færre har godt af nogen læsning, men hele folket kunne i myterne se et klart bevis på, at nordboer ikke er tyskere (hvad Jacob Grimm havde 
påstået $\mathrm{i}$ sin tobinds Geschichte der deutschen Sprache, 1848). Andenudgaven af Nordens Mythologi 1832 kom dog først i 1870.

Men den almindelige genoplivelse af Nordens historisk-poetiske sindbilledsprog lykkedes ikke. Såvel 1848-1850-krigen som katastrofeåret 1864 afføder megen lejlighedsdigtning, men ingen mobiliserer effektivt de gamle aser. Grundtvigs teoretiske udtalelser om brugen af nordiske guder bliver sparsomme, hans holdning tydeligere og tydeligere opgivende og resigneret. I artiklen Overgangs-Tiden i Danmark. II i Danskeren 17. februar 1849 overskuer Grundtvig sobert sam- og modspillet mellem rigets ægte gamle stænder og de uægte moderne. Det sker uden billedsprog lige til slutningen, hvor han ikke kan modstå sammenligninger med Frodes guldkværn og Rolf Krages guldsæd på Fyrisvold. Men straks derefter sukker han:

Dog, lad mig nu ikke igien gaae hen og giøre, som jeg pleier, og slutte en klar Udvikling med et Par dunkle Ord, der vel for mine Øine samler alt det Folkelige i sin rette Brændpunkt, men i de fleste Læseres Øine kaster alt tilbage i det gamle Mørke! Vist nok maa Grunden hertil, som ene ligger i den herskende Mangel paa Fortroelighed med Danmarks Krønike og det deri hvilende Billedsprog, ogsaa nødvendig hæves [..]

Inden for kredsen af sine egne fortsatte Grundtvig mundtligt med mytologien, således $\mathrm{i}$ noget omfang i tolv populært ræsonnerende foredrag i februar-april 1853, Høinordens Historie (Fasc. 368, afskrift ved Svend Grundtvig i Fasc. 369). Endnu i sine kirkehistoriske forelæsninger 1861-63, trykt i 1871 under titlen Kirke-Speil, finder Grundtvig nordisk mytologi uden sidestykke på grund af Balders død, Ragnarok, forliget mellem aser og vaner og Frejas længsel. Mens kælenskab og vellyst, usselhed og fejhed udtrykker en dyriskhed, der sidestiller mennesker med de umælende, er myterne tegn på åndelighed, da »ethvert Folks saakaldte Mytologi er dets Profeti, er Spejlet, hvori man ser dets særegne Forhold til Aand og Hjærte, og dermed til Menneske-Livet, som er de umælende ubekjendt « (US X, s. 198). Senere i foredragene foretager Grundtvig en forbløffende ekskursion til det hedenske Norden. Det sker, hvor han håber, at en åndelig kristendom må vise sig i det moderne Danmark i »en ganske egen, kvindelig, lidt nedbøjet, men dog halvdronninglig Skikkelse« (US X, 
s. 325). Da slår det Grundtvig, at skønt et sådant håb nu kan knyttes til et ord af Kristi egen mund, melder en nordisk myte sig dog også, den om ægteskabet mellem Idunna som vort kvindelige modersmål og Brage som digterguden. ${ }^{14}$ Han undskylder sig:

[..] naar jeg nu bruger Æventyr, da er det tilsyneladende kun af gammel Vane, som for Løjer, og er i alt Fald kun tillige for at følge min Overbevisning om vore folkelige Æventyrs Dybde og deres levende Indtryk paa Folket i alle Livsaldere. Saaledes synes mig i dette Øjeblik, at danske Folk umulig kan faa en mere levende Forestilling om, hvad jeg mener med den danske Kristendoms uformodentlige Fremkomst og Virkning, end ved derpaa at anvende vort gamle Æventyr om Halvgudinden Idun$n a[.$.

I 1861 fastholder Grundtvig i forordet til 2. udgave af sine dramatiske optrin af Nordens kæmpeliv, 1809-11, sin høje vurdering af nordisk mytologi som et gyldigt verdenshistorisk overblik over menneskelivet overalt, hvor nordisk kæmpeånd har hersket, altså i Skandinavien og England. Men den 78-årige mand må mismodigt tilføje:

Skade maa jeg derfor kalde det, at hvad der blev saa tidlig og saa godt begyndt med Øhlenschlagers Vaulunder, Thors Reise, Hakon og Balder, og med min »Nordens Mythologi« (1808) og mine Nordiske Samtaler, hverken af os eller af andre Skjalde blev fremmet, men derom nytter det aldrig at gaae i Rette med Nogen, da Skjalde ligesaalidt som andre Folk giør andet godt, end hvad de har Lyst og Evne til; og skiøndt mig stundom synes, jeg endnu har Lidt af begge Dele, faaer jeg dog nu neppe Stunder til at vise det.

(US I, s. 746)

Samme år udsendte Grundtvig ufortrødent en tekstkritisk udgave, Beowulfes Beorh, af det angelsaksiske epos, han i 1820 havde oversat som Bjowulfs Drape. Trods et nyt oplag af den danske gengivelse i 1865 lykkedes det aldrig Grundtvig at gøre Beowulf og Grændel til danske folkelige skikkelser. 


\section{Grundtvigs digteriske praksis}

I sin kildetro periode skriver Grundtvig loyalt i forlængelse af myterne. I anledning af Willemoes' død i træfningen ved Sjællands Odde 22. marts 1808 indrykker Grundtvig 26. maj et mindedigt i tidsskriftet Ny danske Tilskuer. Digteren ser i en vision Odin i Valhal sende en valkyrie til jorden for at hente en helt. Da der gøres plads på bænken mellem Søren Norby og Peder Skram - to søhelte fra det 16. århundrede - forstår Grundtvig, at det nu må gælde Willemoes, og han synker sammen i gråd. Dette er en moderniseret version af dødsdigtet over Hakon Adelsten (Hákonarmál), men det vakte ingen genklang i tiden. Den klassiske tekst om Willemoes skrev Grundtvig i 1810 med Kommer hid, I Piger smaae! - uden mytologi.

Et første eksempel på fri mytetolkning ses i gendigtningen fra 1815 af eddakvadet om tyveriet af Thors hammer, Prymskviða. Grundtvigs version er gemytlig, tre gange så lang som originalen, og har et politisk budskab, der formelt hører hjemme på dronning Margrethes tid, men naturligvis handler om Kielerfreden 1814. Danmark er Freja, Norge er Thor, hammeren er båndet eller foreningen mellem dem, og Sverige er den tyvagtige jætte Thrym. Nyt er det, at Grundtvig sætter digtet ind $\mathrm{i}$ en ramme med en lærd udgiver og en bondsk kommentator, vel inspireret af Holbergs fiktionsapparat omkring det satiriske epos Peder Paars. Det tillader en på én gang alvorlig og humoristisk behandling af stoffet.

Et anderledes eksempel på fri brug ses i Bjarkemaalets Efterklang (»Soel er oppe«). Grundtvig gendigter her æstetisk perfekt Bjarkemålet efter Snorre som en morgen-opsang (modsat Saxos natteskildring) til erindring om de trofaste hirdmænds kamp til sidste åndedræt for deres konge. Det trykkes i Danne-Virke i 1817. Manuskriptet viser imidlertid en overraskende førstetitel: »Bjarke-Maalets Efter-Klang til Morten Luthers Minde« (Fasc. 387.100 324r). Skønt digtet er totalt blottet for henvisninger til kristendommen, har Grundtvig åbenbart ment, at det kunne bruges pronominalt, rejse en energisk kamplyst til glæde for den søvnige danske lutherske kirke i reformationens jubilæumsår 1817. Det opgav han så i trykversionen, men et andet digt, han offentliggjorde sammesteds til Morten Luthers minde, blander ubekymret nordiske myter og kristelige billeder.

Det gør Grundtvig også i kvadet Nyaars-Morgen, 1824, hvis argumentationsmateriale hentes fra frie kombinationer af nordisk-mytolo- 
giske billeder, og hvis pointer ligger i det dunkle og antydende. Ikke mindst må nordisk mytologi holde for i en række af Grundtvigs dødsdigte. Amtmanden i Præst $\varnothing$, grev Danneskjold huskes i 1823 som en Forsete (asernes forligsmand), ungdomsvennen Povel Dons i 1843 som en Skirner (guden Freis uegennyttige tjener), Thorvaldsen i 1844 som en lysalf og dværgekonge, og Steffens i 1845 som en blanding af Heimdall (asernes vogter) og påskeenglen. I en hyldest til Thorvaldsen i 1838 gør Grundtvig ham til en Vølund, der genvinder Thors tabte hammer - skønt mytologien ikke forbinder disse to personer. I et utrykt digt fra 1864 om Balders bålfærd véd Grundtvig endog det, som er mytologiens store gåde: hvad Odin hviskede i øret på sin søns lig - naturligvis et kristent »kom igien!«.

Der kunne nævnes mange flere eksempler på Grundtvigs frie mytetolkning. Blandt dem viser især det berømte indledende RimBrev til Nordiske Paarørende i Nordens Mythologi, 1832, hvorledes Grundtvigs indforståede billedbrug kommer til at stå i vejen både for selve udbredelsen af mytologien og for de universelle ideer, han vil viderebringe gennem den. ${ }^{15}$ Princippet står udtalt i samme bog: husk, at »det for os giør liden eller ingen Forskiel, hvad der svævede for Mythe-Smeden, naar kun hvad vi lægge i Mythen er godt at giemme, og ligger magelig i den« (US V, s. 636). Et farligt vilkårligt kriterium.

Nogle smagsprøver kan gives. Det er endnu rimeligt, at 1832bogen kalder Urds brønd for begejstringens dybe væld med den levende ordstrøm (s. 532). I 1844 ses myten om Tyrs tab af sin højre hånd $\mathrm{i}$ Fenrisulvens mund, mere søgt, som udtryk for kimbrernes indvandring og forsvinden i romerriget, båndet af kvindeskæg, kattefodtrin, fiskeånde og andre umulige ingredienser bliver tegn for frankernes afgrænsning af romerriget ved Rhinen, og sværdet $i$ ulvens gane symboliserer normannerne, som kneblede den romerske ulv, så den latinske tuden over barbari hørte op (US VIII, s. 596). I skolebogen fra 1847 foreslår Grundtvig, at det historiske forhold mellem aser og jætter kan afbilde

det videnskabelige Forhold mellem Historien og Physiken, der ogsaa til Hverdagsbrug kan findes stridigt nok, men bliver dog kun uforligeligt, naar enten Historien har opgivet Aanden og stræber som en Gienganger at kyse Livet af Folk, eller naar Physiken trodser paa det Haandgribelige, som det eneste Virke- 
lige, og stræber med hjerteløs Selvklogskab at forstyrre Aandens historiske Verden i Menneske-Livet, som idel Gøgleri og Blandvark.

Stadig i skolebogen mener han, at Thors fiskeri efter midgårdsormen betegner »Nordboens Forhold til Paven med Fiskerringen « - også i den forstand, at stridens emne, bryggerkedlen, Thor skal låne, således får god mening, »thi Spørgsmaalet er jo om et Kar (en virkelig Form), der kan rumme alt det agte Aandelige « (s. 193-194).

Loke identificerer Grundtvig med

den klarøiede, igrunden hjerteløse, men dog, efter Omstændighederne, hardtad uundværlige Stats-Klogskab eller Politik, der netop staaer i et ligesaa dunkelt, slibrigt og foranderligt Forhold til Historiens Aand og dens Kæmper, som Loke til Odin og Thor, eller Achitofel til Kong David.

Desværre ville offentligheden ikke vide af dette sindbilledsprog. Nordens Mythologi, 1832, fik ganske vist en udførlig og sympatisk anmeldelse i 1839 af Christian Flor (optrykt i bogform 1865). Men da Grundtvig 21. maj 1839 i sin nye diskussionsforening Danske Samfund - en københavnsk aftenskole godt fem år før Rødding-højskolens åbning - lovede at ville gøre møderne til »et smukt Arbeidshuus « for vore gamle guder, tog han fejl. Hans publikum af studerende og håndværkere ønskede ikke nordisk mytologi. Den 17. marts 1840 erkender han, at hans anskuelser vedrørende Nordens myter »kun tiltaler meget Faa«. Af de godt 100 bevarede oplæg fra Grundtvigs hånd til møderne handler kun de ti om nordiske myter og sagn. ${ }^{16}$

Et endnu markantere nederlag led Grundtvig under Treårskrigen i diskussionen om et monument for det sejrrige udfald fra Fredericia 6. juli 1849. Der blev holdt en konkurrence mellem to udpegede billedhuggere, H.W. Bissen og J.A. Jerichau. Bissen stillede med den tapre menige landsoldat, Jerichau med en Thor. Grundtvig tager sagen op i sit tidsskrift Danskeren 18. maj 1850. Han går ind for Thor, for hvad skal en fader om en generation svare sin lille dreng, der spørger efter den anonyme soldats navn og bedrift. Grundtvig advarer i det hele taget imod at gøre »det nærværende Øieblik til Maalestok for hele 
Fremtiden « (III, s. 297-298). Han ser altså ikke samtidsfigurens symbolværdi. I $\emptyset v$ rigt ville Grundtvig frem for Thor foretrække den Uffe hin Spage, som Bissen efter byrygter også havde givet en skitse til - for Uffe var en ægte »'Holger Danske' i sine hjemmegjorte Klæder og i den Skikkelse under en af hans tidlige Aabenbarelser, hvori vi kan og bør holde fast paa ham« (s. 298-299). Rygtet var sandt, to lerskitser af Uffe står endnu på Glyptoteket, men en afstemning blandt interesserede bidragydere i København en måned efter gav 73 stemmer til den ukendte soldat, kun 19 til Thor. Derved blev det; statuen i Fredericia blev afsløret i 1858.

Endnu mere forbløffende er Grundtvigs forslag i samme artikel om, at Peter Fabers marchsang Dengang jeg drog afsted, 1848, som typisk udtryk for krigens stemning bør erstattes af et nyskrevet mytologisk værk af en af vore nulevende skjalde, »en smuk Thors-Drape, hvori Kampen med Hrungner Jette var vittig anvendt baade paa Frederis-Slaget og paa den hele Krig!« (s. 298). Det skete som bekendt ikke. Det vittige kunne vel have ligget i parallellen mellem jætten Hrungner, der ved en forvirring ender som gæst i Asgård, drikker sig fuld, udfordrer Thor og dræbes i en tvekamp skønt støttet af en lerjætte, og slesvig-holstenernes overmod, danskernes kampkraft og det tyske forbunds ineffektive bistand. Skønt Grundtvig i 1808 ikke havde haft det mindste tilovers for Hrungner-sagnet, for »Noget Uslere eller Flauere findes ei let « (US I, s. 284), kunne den nulevende skjald være ham selv. I Danskeren for 28. september 1850 trykte han i hvert fald et fortællende digt Odin Langskiag og Rungner Graasteen (III, s. 601-607; PS VII, s. 323-327), som dog efter 24 fyldige strofer standser $f \phi r$ tvekampen mellem Thor og jætten. Fortsættelse fulgte aldrig, og teksten er bestemt ikke inspireret.

Derefter opgav Grundtvig nærmest at vinde et nutidigt publikum med sit mytologiske sindbilledsprog. Alligevel kunne han for sit eget vedkommende som digter ikke klare sig uden de nordiske myter. Store dengang utrykte digte som Dansk Ravne-Galder, 1860, Havamaal, 1866, og Hфjnordens Rimkrønike, 1867, har titler, der er mere mytologiske end indholdet. Men i skæbneåret 1864 gendigter han faktisk Nordens Myther i en version, som først trykkes på 128 sider i 1930 - samtidig med Tom Kristensens roman Harvark! Og i kladder af vekslende færdighedsgrad er der fra 1865 bevaret flere hundrede sider af et stort trøsteskrift til det danske folk efter krigen og nederlaget. Det er her en gennemgående pointe, at Danmark nu må vente 
og græde efter Slesvig, som Freja græd guldtårer over sin bortgåede ægtemand Ottar, så vil danskerne som enken fra Nain i tro på Kristus få den tabte søn tilbage. Men Grundtvig gør tilsyneladende ikke noget for at få alt dette trykt. Så han det utidssvarende i manéren uden at kunne holde sig fra den? Eller er der en bedre forklaring?

\section{Havariopgørelse}

Der kan opregnes en del mulige årsager til projektets manglende succes.

Det individualistisk orienterede, genidyrkende 19. århundrede egnede sig ikke til kollektivt at antage og i enighed at bruge ét bestemt billedinventar. Tankegangen er set fra et nutidsstade for bagudrettet og gammeldags, men dengang havde man jo faktisk to eller tre fælles referencerammer for billedsprog. Én udgøres af antikkens myter, sagnhistorie og poesi (som Ovids Forvandlinger, Vergils Aneide). En anden hentes i senantikkens og middelalderens naturvidenskabelige bestiarier, hvis indhold snart tolkedes kristent: enhjørningen, salamanderen, pelikanen. En tredie dannes af den kristne billedverden $\mathrm{i}$ Bibelen og $\mathrm{i}$ legenderne om hellige mænd og kvinder. At disse udtjente fællessprog nu ikke mere lod sig erstatte af et nyt moderne, kunne man ikke vide omkring 1800 . I stedet vandt originalitetsbegrebet fra midten af det 18. århundrede - med Edward Youngs essay Conjectures on Original Composition, 1759 - stærkere og stærkere frem og blev netop i Grundtvigs levetid til æstetisk norm.

Grundtvigs særegne, personligt følte opfattelse af den nordiske mytologis universalhistoriske præg bevirker,

at Begivenhederne, Kampen og Storværket, er Hoved-Sagen, og Personlighederne, mest som Redskaber, en Bisag, hvorfor de umulig kan findes saa selvstændige, afrundede og udprægede som de Graske Guder, men lever i et underligt Fallesskab og er immer i Bevagelse, hvorved de, efter Omstændighederne, baade skifte Ansigt, og udvikle Egenskaber, som man slet ikke havde ventet hos dem.

(1847-mytologien s. 155). 
Det er derfor bevidst, når Grundtvigs mytologiske figurer og situationer savner plastisk anskuelighed. De skal være fleksible, ustabile, flimrende. ${ }^{17}$ Hvad der kan være en fordel for mytetolkeren og hans efterfølgere på folkehøjskolerne skader imidlertid den folkelige appel, der kunne ligge $i$ en umiddelbar genkendelighed. Ikke engang en ulærd bonde kan være i tvivl om, at en Neptun med trefork på toppen af Christian IV's springvand i Frederiksborg slotsgård står for havet, men hvorledes Frejas guldgråd skal forstås, kræver kvalificerede overvejelser. Noget lignende gælder gudernes omgivelser, ejendele og hele naturen. Netop på grund af de nordiske guders enhed bliver Nordens fabellære - der beskriver sporene på jorden af det højere liv - lutter forvirring, »thi der var da intet Baand, som hindrede Digteren, Tænkeren og Iagttageren fra at bevæge sig efter eget Tykke i den aabne, vide Mark« (US I, s. 339).

Hertil kommer, at Grundtvig efter 1815 først og fremmest $\mathrm{g} \varnothing \mathrm{r}$ meget ud af de mindre kendte guder, eller rettere sagt gudinder: Freja, hendes datter Gersemi, Idunna. Af mandlige skikkelser foretrækker han de tøvende, men ordholdende og til sidst handlekraftige mænd: Amlet, Folke, Uffe hin Spage, den lille Skjold på neget, Frode Fredegod frem for Odin og Thor; særskilt interesse får den ofrede, passive Balder.

I sit foredrag Om Skandinavismens Forhold til den almindelige Cultur, 1844, slår J.N. Madvig præcist ned på den vilkårlighed, den Grundtvigske myteudlægning åbner for: kun hvis man medbringer refleksion fra en ganske anden skole end den, myterne selv tilhører, kan man få »en vis almindelig og sammenhængende Anskuelse« ud af dem. Og så falder hugget: »hvis man ellers ikke, hvad der rigtignok er beqvemmest, i fuld Tillid til sin Aands Identitet med den ægte nordiske Oldtids, gjør den førstes hele Subjectivitet til Maalestokken for Mythologiens Indhold, hvorved man da rigtignok, hvad Indholdets virkelige Betydning og Grund angaaer, kunde have sparet sig denne hele Omvei til Mythologien og uden Omsvøb ligefrem talt af sit Eget« (særtryk s. 16). Det er jo just det sidste, Grundtvig gør med held i sine bedste folkelige og dog livsfilosofiske højskolesange og læredigte.

Grundtvigs egne fors $\varnothing \mathrm{g}$ på at bruge mytologien gik i alle tilfælde mestendels under i lange digte, som næsten ingen (dengang) læste Nyaars-Morgen, 1824, Nordens Aand og Nordens Guld, begge 1834, Skjaldelivet i Danmark. (En Mundsmag.) fra 1851. Blandt de Grundt- 
vig-sange, som er populære i dag, er vist ingen af de mytologiske. ${ }^{18}$

Grundtvigs datering af Völuspá til den ældste hedenske tid (5. århundrede) blev ændret til ca. 1000, altså sen vikingetid, af den positivistisk-filologiske forskning (S. Bugge 1881-96); i $\emptyset$ vrigt er digtets høje ælde anfægtet allerede i 1808 af Jens Møller. Hermed bortfalder eller svækkes Grundtvigs tese om nordisk mytologi som belæg for forfædrenes monoteisme i hedenskaben. Grundtvig hævdede selv den tidlige datering $\mathrm{i}$ alle sine mytologier $\mathrm{i}$ fast overbevisning om, at digtet er ældst af alle, skrevet af en nordisk Homer, formentlig hos anglerne kort efter deres udvandring til England (US V, s. 486).

Tanken om at anvende de nordiske hedenske myter eksistentielt, i en alvorlig religiøs, altså kristen, livstolkning er for dristig for tiden. De kunne upåtalt udlægges som forvansket historie (P.F.Suhm, 1771) eller forvansket naturkundskab (Finn Magnussen i 1820'rne), men ikke som en art nationalt Det Gamle Testamente (Martin A. Hansens udtryk i Orm og tyr, 1952).

Den store modstander, antikken, stod trods alt stadig stærkt i uddannelsessystemet, som næsten alle det 19. århundredes forfattere havde været igennem. To tusind års kunst havde vænnet publikum til antik mytologi. I hverdagen havde københavnerne også fået antikken for $\varnothing j \mathrm{je}$ i den genopbyggede bys arkitektur: Amalienborgs Kolonnade 1794, Råd- og domhuset 1803-15, Frue Kirke 1811-29, Universitetet 1831-36, hvortil kom nyklassicismen i privathusene. Antik mytologi kunne uden konflikt bruges i almindelig dannet omgang af gode kristne, fordi ingen drømte om at tro på disse myter: de var blevet ren æstetik. Måske var det fatalt, at berømtheden Thorvaldsen hele sit liv holdt sig borte fra nordiske myter. De københavnske kunsttempler Thorvaldsens Museum 1839-48, åbnet 18. september 1848, og Glyptoteket 1892-97, udbygget 1901-06, var i høj grad helliget antikken. Den gennemkultiverede satiriker Frederik Paludan-Müller skriver i 1848 i Adam Homo (2. del) ironisk om, at Danmarks genius skal tvinges til at forny sit sprog på oldnordisk:

[man] raaded ham, for Mælet ei at miste, At skaffe sig en Tunge, der sig skrev

Fra det Ginnungagab, det underjordiske, Hvor Kragemaalet er det Gammel-Nordiske. 
Endnu Georg Brandes og Julius Lange formelig badede sig som unge i den antikke kunst og dens genopvakte form hos Thorvaldsen. De måtte nøjes med for det meste halvsløje reproduktioner, men deres billedhunger blev mættet af antikke sk $\varnothing$ nhedsindtryk. ${ }^{19}$

Målt mod antikken havde den nordiske mytologi så godt som ingen originale billedst $\varnothing$ tter (eller malerier) efterladt sig - i hvert fald ikke noget, som tiltalte det 19. århundredes smag. Goethe erklærer i Dichtung und Wahrheit, 1813, at nordisk mytologi - som han læste på latin i Resens 1665-edda - er »Nebelbilder, ja bloße Wortklänge«, uegnet til plastisk fremstilling, unddraget objektiv anskuelse og derfor langt overgået af antik kunsts gudestatuer.

Selv om der havde været billedstøtter bevaret, ville Grundtvig sandsynligvis have taget afstand fra dem, da han hele sit liv regnede bildende kunst for den laveste af alle kunstarter, mens Ordet (det mundtlige, digteriske, sungne) stod højest på hans rangliste.

I det hele taget voldte de nordiske guder tidens bildende kunstnere problemer. Enten bliver de nemlig græsk-romerske guder i forklædning, kristne skikkelser mildt nordiseret eller blot kostumerede figurer. ${ }^{20}$ Fine kunstnere som H.E. Freund og Bissen skabte med henholdsvis Loke-statuetten 1822 og Ragnaroksfrisen på det nye Christiansborg 1823-41 smukke, men enkeltstående eksempler på, at stoffet faktisk lod sig forme. Professor N.L. Høyen fulgte dem op i 1840'rne med foredrag på Kunstakademiet om en hjemlig mytologi tolket i lys af nulevende almue. Populariteten udeblev imidlertid. Selv det bedste udtryk for de nordiske myter, Lundbyes, Skovgaards og Frølichs vægmalerier ved Den Nordiske Høitid 13. januar 1845, rekonstrueret af kunstnerne $\mathrm{i}$ en fornem billedbog samme år (optrykt i 1945), er aldrig blevet en del af dansk folkeliv.

Den litterære smag var heller ikke varigt gunstig for oldtiden. Den ældre danske romantiks historiserende skole blev fra omkring 1820 , med stigende styrke i løbet af 1830 'rne-40'rne, afløst af en levende sans for nutiden, hverdagen og folket. Oehlenschlägers patetiske historiedramatik føltes således forældet, da digteren i en subskriptionsindbydelse i 1842 meddelte, at prisen for hans Samtlige Varker ikke ville overstige omkostningerne ved par års avisabonnement. Folk lo ad den gamle digters naivitet - og foretrak avisen. Tidens medium var de politiserende dagblade og tidsskrifter, ikke opbyggelige nationale sørgespil. Dagens helte kom nu demokratisk ud af bondestanden, ikke fra fjerne mytiske tider eller fra historiebøgerne. Oehlenschlägers 
sidste versfortælling Regnar Lodbrok. Et Heltedigt, udgivet i december 1848 (trykår 1849), havde ingen opsigt vakt. Treårskrigens yndlingsfigurer er den tapre landsoldat (både i Fabers sang 1848 og med Bissens statue i Fredericia 1858) og den lille hornblæser (fra H.P. Holsts digtning 1849). Bjarkemaalets Efterklang kunne ikke klare sig i konkurrencen.

Det påfølgende moderne Gjennembrud er ifølge Georg Brandes' program internationalt orienteret og afskyer dansk provinsialisme. Nutidssamfundet og hverdagens problemer dominerer dagsordenen. Bruger digterne myter og sagn, tager de dem fra den antik, der var så populær i det beundrede Frankrig, og kalder som Vilhelm Topsøe i 1875 en roman om en hjemvendt udlandsdanskers og ingeniørs kærlighedskrise for Jason med det gyldne Skind eller som Herman Bang i 1883 en roman om en degenereret adelsdame for Fadra. I begge tilfælde bliver de antikke navne - som senere hos Freud etiketter klistret på personernes individuelle psyke.

Endelig bet $\varnothing \mathrm{d}$ skandinavismens politiske nedtur efter Sverige-Norges »svigt« i 1864 måske også, at de nordiske myter blev mindre aktuelle og mindre populære.

Er der således en hel række årsager til, at Grundtvig måtte lade sin kære nordiske mytologi træde i baggrunden, skal i hvert fald én modifikation med. En del af hans intentioner blev faktisk virkeliggjort på de såkaldt mytologiske højskoler med Chr. Flor i Rødding 1845-46 og navnlig Ludvig Schrøder på Askov fra 1865 til på den anden side af århundredskiftet, i det 20. århundrede med Aage Møller 1921-41 på Rønshoved. Højskolernes behov aff $\varnothing$ dte andenudgaver af Nordens Mythologi, 1832, i 1870 og af Brage-Snak, 1844, i 1876. ${ }^{21}$ At nordisk mytologi har en vis fremgang som sindbilledsprog på folkehøjskolerne, skiller den imidlertid netop ud fra det almindelige hovedstadscentrerede åndsliv, så den ikke ænses i den moderne litteratur.

\section{Ironisk slutreplik}

Det lidet, som faktisk er blevet et bevi1/4õnget ord på dansk af Grundtvigs mytologiske billedsprog, misforstås næsten altid - vendingen »Frihed for Loke saavelsom for Thor «. Når den optræder i mundtlig form eller $\mathrm{i}$ avisernes ledere, tror brugerne gerne, at de dermed går 
ind for en uendelig og forskelsløs tolerance. ${ }^{22}$ Udtrykket skal - forventeligt ud fra Grundtvigs yderliggående liberalisme - angive, at godt og ondt skal have lige kår (fair play) i den kamp om og for værdier, tilværelsen bør udgøre. Dette er imidlertid langt fra Grundtvigs mening. Det onde, den Onde og døden kan han som kristen ikke gøre noget for at sikre overlevelsesbetingelser.

Tekstsammenhængen er Rim-Brev til Nordiske Paarørende, indledningsdigtet i Nordens Mythologi, 1832 (US V, s. 385). Her står for det første guderne ikke ubetinget for det gode: de giver undertiden efter for jættetilbøjeligheder, som de må reddes hjem fra - hvad myterne udtrykker i form af ubetænksomme kærlighedsaffærer mellem guder og jætter. For det andet fremstiller Grundtvig entydigt jætterne som de modstandere, der skal nedlægges - det onde. De er det rent materialistiske, det selvrådige, det, der ødelægger ved ild, vand, pest og hunger, ja, ved rovdyroptræden som ulve og bjørne. De markerer en uhyggelig forening af åndløshed og hjerteløshed.

Men sådan er Grundtvigs opfattelse af Loke ikke. Han kan ikke placeres så håndfast. Han er både as og jætte. Han er nok fader til tre uhyrer, Midgårdsormen, Fenrisulven og Hel, men han er også fostbroder til Odin. Hans drillende vid - gerne betegnet som Fornuft - er af ånd, og hans tilstedeværelse blandt guderne er med til at holde dem vågne, tirre dem til sejrrig kamp mod jætterne.

I det tidligere nævnte manuskript Mythologiens Vard fra ca. 1823 forstår Grundtvig Odins fostbroderskab med Loke - asernes syndefald - som den historiske ånds forbindelse med »den tvetungede Klogskab, for at forevige sig i Verden (Verdens-Klogskab) « (Fasc. 253 6v). Lidt senere ræsonnerer han: »Loke er Fornuften, tvetydig som den tages i Sproget og findes i Mennesket, Selv-Klogskaben i alle Maader, som, paa sin høieste historiske Punkt, idelig halter mellem Aser og Thurser, mellem Aandens og Kroppens Verden, mellem det Ædle og Nedrige, mellem Kiækhed og Feighed, Ærlighed og Falskhed, men narres og spotter dog i Grunden med Alt undtagen med sig selv « (8v). ${ }^{23}$ Der er i Loke kim til en bedre opfattelse - hans vankelmod er tegn på et endnu uudviklet åndsliv.

Derfor kan Grundtvig noget overraskende resolut fastholde, at hvis man binder Loke, binder man i samme øjeblik også sine egne åndelige hænder (US V s. 385, 702-703). I Brage-Snak skriver han, at aserne aldrig kan undvære Loke, han er med i alle deres store begivenheder som »Sjaelen i Øieblikket eller i den narvarende Tid «. 
Han fortsætter med at give de gamle mytesmede ret, dengang de anså aserne for at gå i barndom, »saa de iblinde bandt deres egne Hænder for at hævne sig paa Loke«. Det er nemlig det samme, mennesket gør, når det »stræber at helbrede Tidens Foranderlighed og at fængsle Øieblikket til sine forstenede Tanker, Lærebygninger og Indretninger, som Loke til de flade Stene«. En verdenshistorisk følge af at lænke Loke ses i Frankrig fra Ludvig XIV's tronbestigelse frem til revolutionen og Napoleon, hvor Loke og ulven kom løs, mens Loke i England og Rusland - som henholdsvis en As-Loke og en UdgårdsLoke - havde fået lov til levende virksomhed for Europas frelse fra franskmændene. Loke er altså øjeblikkets »Frisprogs-Mund«, som Thor er dets »Helte-Arm« (US VIII, s. 661-663, 666). Lokes uberegnelige bevægelighed er et symptom på liv - også åndsliv.

På den hjemlige arena havde Grundtvig selv i årene 1826-37 ved dom været underlagt enevældens specialcensur. Som rigsdagsmand talte han derfor gerne og tit om vigtigheden af lovhjemlet trykke- og talefrihed. I artiklen Bog-Vaesen, Trykke-Frihed og Presse-Lov i Danmark. III argumenterer Grundtvig i Danskeren 27. april 1850 mytologisk:

Jo mere vi nu kiender til det Vennelag, som Aser og Vaner udgjorde, des klarere seer vi, at de alle, selv Lurendreieren Loke, havde deres Frisprog, saa Ordet var frit som Fuglen i Luften, og selv Asernes Fiender, selv Jetterne kunde frit sige hvad de vilde, med mindre de, som Jetten Vafthrudner, udæskede Odin til en Ord-Strid og satte derved selv deres Hoved paa Spil.

Grundtvig hilser denne situation som et godt billede på en fri forfatning, hvor ordets frihed er det vigtigste, og hvor selv kongen er underlagt en grundlov.

Loke er i Grundtvigs mytologiske sindbilledsprog ikke det onde, men hvad man kan kalde et åndfuldt og begavet menneske, som ikke er troende, men har forudsætninger for at blive det eller i hvert fald for at gavne troen. Han er langtfra altid god, men kunne vælge at være det. Et problematisk, men ikke håbløst tilfælde.

Det bevises af Grundtvigs moderne Loke-paralleller. I Brage-Snak roser han omgangen med ordets og dådens Mjølner-hammer hos Holberg, »der, i Pernilles Skikkelse, var som Loke med at hente den, og 
laande den siden jævnlig, især i Per Paars og Niels Klim, saa LatinSkolen glemmer aldrig hans Dommedags-Slag« (US VIII, s. 632). Sammesteds udnævner Grundtvig sin fætter Henrich Steffens til en Loke (s. 577), og han beskriver Jens Baggesens »Loke-Smil« (s. 624). Det sidste passer med, at Grundtvig allerede i 1818 havde bestemt Baggesen som en mand, hvis vittighed havde lynglimt af åndelig forstand. Han var en mand med et falkesyn, en mand, hvis dyrkelse af $\varnothing$ jeblikket er værdifuldt og derved forskelligt fra den samtidige libertinske forfatter T.C. Bruuns dyrkelse af det sanselige øjeblik - og fra måske også Oehlenschlägers kødbilledhuggeri i hans dårlige ting fra 1810'erne.

Der er en historisk ironi i, at den kendteste overlevende vending fra Grundtvigs forsøg på en moderne genfødelse af Nordens myter så tit bruges forkert. Også i denne enkelthed forbliver hans dristige fors $\emptyset \mathrm{g}$ på at skabe et nationalt mytologisk billedsprog et mislykket eksperiment.

\section{Noter}

Afhandlingen udspringer af et oplæg på The Eighth International Saga Conference i Göteborg 12. august 1991, gentaget i udvidet form som foredrag i Det Kongelige Danske Videnskabernes Selskab på medlemsmødet 15. april 1993. En engelsk version, Grundtvig's Norse Mythological Imagery - an Experiment that Failed, er trykt i Andrew Wawn (red.): Northern Antiquity. The Post-Medieval Reception of Edda and Saga, 1994, s. 41-67. Teksten er i nærværende version kraftigt udvidet med unders $\emptyset$ gelser i en række utrykte manuskripter.

Henvisninger til Grundtvig-tekster gives i selve fremstillingen i parentes med de gængse forkortelser: $\mathrm{Br}=$ Breve fra og til N.F.S. Grundtvig, ved Georg Christensen og Stener Grundtvig, I-II, 1924-26; Fasc. + nummer = håndskriftkapsel i Grundtvigarkivet, Det Kongelige Bibliotek, København; PS = Poetiske Skrifter, ved Svend Grundtvig og Georg Christensen, I-IX, 1880-1930; US = Udvalgte Skrifter, ved Holger Begtrup, I-X, 1904-09. Grundtvigs manuskripter citeres overalt uden gengivelse af overstregede dele.

Adam Oehlenschläger: AEstetiske Skrifter 1800-1812, ved F.J. Billeskov Jansen, 1980, s. 5. Oehlenschläger gentog i 1830 sit standpunkt i Levnet, I (optryk ved Poul Linneballe og Povl Ingerslev-Jensen, I, 1974, s. 91). 
2 Helge Toldberg: Grundtvig som filolog, 1946; Gustav Albeck: Grundtvigs vej til de norrøne skrifter i Grundtvig-Studier 1953, s. 103-111; Paul V. Rubow: Saga og Pastiche, 1923; Flemming Lundgreen-Nielsen: Det handlende ord, 1980; Helge Toldberg: Grundtvigs symbolverden, 1950; Kaj Thaning: Menneske først - Grundtvigs opgфr med sig selv, 1963; Flemming Lundgreen-Nielsen: Grundtvigs Auffassung der nordischen Mythen in seiner Forschung und Dichtung i Dänische 'Guldalder'-Literatur und Goethezeit. Text \& Kontext, Sonderreihe, Bd. 14, 1982, s. 160-191; Jens Peter Ægidius: Brage-Snak. Nordiske myter og mytefortalling $i$ dansk tradition (indtil 1910), 1985, Brage-Snak 2. Den mytologiske tradition $i$ dansk folkeoplysning $i$ det tyvende århundrede (1910-1985), 1992; Lars Lönnroth: 'Frihed for Loke såvel som for Thor'. Den nordiska mytologin som politiskt redskap i grundtvigiansk bonde- och folkhögskolemiljö, 1979; Lars Lönnroth: The Academy of Odin: Grundtvig's political instrumentalization of Old Norse mythology i Gerd Wolfgang Weber (red.): Idee, Gestalt, Geschichte: Festschrift für Klaus von See, 1988, s. 339-354.

3 Fortalen er blandt andet ilde omtalt i P.-H. Mallets Monumens de la Mythologie et de la Poesie des Celtes, 1756, som "plus ou moins longue dans les divers originaux, mais également futile \& ridicule«, så Mallet afstår fra en oversættelse $\mathrm{i}$ helhed af denne tekststump »ennuyeux \& inutile« (s. 19).

4 Slutningen af 6. forelæsning, Henrik Steffens' Indledning til Philosophiske Forelasninger $i$ København 1803, ved B.T. Dahl, 1905, s. 88; jf. Grundtvigs dagbog for 15 . november 1803, selvkommenteret i 1806, Dag-og Udtogsbøger, ved Gustav Albeck, I, 1979, s. 257-259, hvor en lignende erkendelse med udgangspunkt i et citat fra Addison om Locke og spøgelses- og mørkeangst drøftes.

5 P. Johansen: Nordisk Oldtid og dansk Kunst, 1907; Karin Kryger: Dansk identitet $i$ nyklassicistisk kunst. Nationale tendenser og nationalt sarprag 1750-1800 i Ole Feldbæk (red.): Dansk Identitetshistorie, 1, 1991, s. 322$339,391-399$.

6 I 1832 skriver Oehlenschläger i sit nye tidsskrift Prometheus. Maanedskrift for Poesie, Asthetik og Kritik, I, et kapitel om Malerkunstens Forhold til Billedhuggerkunsten. Han fremhæver atter, som i prisopgaven fra 1800, den skaberkraft, den ubrugte nordiske mytologi kan fremkalde, og mener, at selv om myterne (ifølge Finn Magnussen) ikke skulle være identiske med den historiske oldtidsreligion, er deres oprindelse i det 9.-10. århundrede »noget af det Skiønneste og Mærkværdigste, hvad poetisk Genialitet har frembragt; og det er langt mere forunderligt og utroligt, at slig en Rigdom, 
Sindrighed og Skiønhed skulde findes i enkelte barbariske Hierner, kort før Hedenskaben undergik ved Christendommen, end at den skulde være Levninger af længstforsvundne Aarhundreders samlede Viisdom« (s. 333). Han glæder sig over alle de situationer og emner, nordisk mytologi tilbyder den bildende kunstner, og hilser Freunds tegninger velkommen, skønt de endnu er »lidt for graske«. Sydens mennesker lider ikke af »den nordiske Fedme« og er skønne af krop, »men i de nordiske Ansigter er mere Forskiellighed, mere Fiinhed og Characteer, ogsaa maaskee mere Siæl. Nordens dybe Følelse og Alvor giver dem et Præg, forskielligt fra den græske Skiønhed « (s. 334). Hermed stemmer, at Oehlenschläger lidt før har fremsat en - forsigtig - kritik af selv Thorvaldsens bedste statuer for at mangle de ægte grækeres »naive Jovialitet " og en "vis Ynde og Munterhed « (s. 331-332). Derpå behandler han spørgsmålet om nøgne nordiske guder i det 19. århundredes skulptur. Over for kritiske røster om »barbariske, for Kulden indhyllede Afgudsbilleder« udbryder digteren veltalende: » $\mathrm{g}$ hvorfor indhyllede? Guderne fryse ikke! Solen og Maanen, Skyerne og Lynilden, Blomsterne og det Grønne ere nøgne i Norden ligesom i Syden og saaledes deres Symboler. Symbolerne for aandelige Evner og Sindsbevægelser behøve endnu mindre Klædebond. Og selv enkelte udvalgte Klædebond kunne give Kunstnerens Phantasie Næring, til sindrigt at forbinde det Characteristiske med det Store og det Skiønne. Lad Odin som kraftig Olding, med det skarpsindige, kloge Ansigt, sidde der, med sit Spyd i Haand og sine Ravne $H u$ og Minde paa Skulderen, der sige ham alt; lad Thor staae nøgen i ærlig, heftig, fremfusende Diervhed, blot med sit Styrkesbelte om Lænderne, med sin Handske og sin Stridshammer!« Freja $\emptyset$ nsker Oehlenschläger »klædt som en Bajadere med broget Fugleham om Skuldre og Underliv« (s. 333-334).

Jens Peter Ægidius: Brage-Snak, 1985, s. 52-53, 56.

Helge Toldbergs datering i Grundtvig-registranten til Danne-Virke-tid, 1817, bygger på det spinkle indholdskriterium, at Grundtvig i dette år offentligg $\varnothing \mathrm{r}$ digtet Ragna-Roke, og at Ragnarok er omhandlet i dette manuskript. Kaj Thaning har i tilskrift i Det Kongelige Biblioteks læsesalseksemplar af registranten sat manuskriptet til 1821-23 efter vandmærke og papirtype.

En variant i Fasc. 267.2 1r har: officiel. februar 1824 , oktober 1824 til 1 . maj 1825 , samt senere. 
11 Flemming Friborg: Dansk Guldalder-skulptur - i Thorvaldsens skygge, 1994, s. 11, 14-18, jf. Peter M. Hornungs anmeldelse i Politiken 3. juni 1994.

12 Udtrykket er en lidt overraskende allusion til Fil. 2.7, hvor det bruges om Kristus som menneske.

13 Bortset fra stavemåderne er der ordret overensstemmelse mellem Rasks udgave og den nye tekstkritiske arnamagnæanske i Edda Snorronis Sturlai, I, 1848, hvis fortale er dateret 29. december 1848. Der er dog ingen belæg for at antage, at Grundtvig forholder sig til sidstnævnte.

14 Idunna-myten har Grundtvig udlagt mere vagt og uprofileret i 1832-mytologien, angiveligt på grund af den forvirrede kildesituation (US V, s. 661670). Udlægningen i Kirke-Speil er tidligere lanceret i Om Nordens videnskabelige Forening i Brage og Idun, 1839 (Grundtvigs Skoleverden, ved K.E. Bugge, II, 1968, s. 162), i Grask og Nordisk Mythologi for Ungdommen, 1847, s. 151-154, samt i digtet Skjaldelivet i Danmark i Danskeren 12. april 1851, str. 16-24 (IV, s. 230-233). Grundtvig har ifølge 1847-behandlingen udledt myten af eddadigtene Grímnismál og Lokasenna, af Snorres Edda (æblerne), Skáldas Bragarøður og Hrafnagaldr Óðins (hendes oprindelse). Kirke-Speil er i US X helt igennem trykt i Svend Grundtvigs retskrivning.

15 Teksten er momentvis ubegribelig selv for kendere af Grundtvigs billedverden; Holger Begtrups »Oplysninger« til den i Tidsskrift, III Aargang, 1907, s. 109-128, er desværre mest en genfortælling i let sprogføring, med overspringelse af de prekære enkeltproblemer.

16 Foredragene, som er bevaret i Fasc. 364,I-II med afskrift af Svend Grundtvig i Fasc. 365, fordeler sig således: 21. maj og 18. juni 1839 om brug af nordiske myter, 22. oktober 1839 om Phønix-fuglen, 26. november 1839 om Thor, Hrungner og Thrym, 18. februar 1840 om Balder, 9. marts 1841 om Valhal, Odin, Thor og Loke, 4. januar 1842 om Balders genkomst, 14. april 1843 og 13. februar 1844 om bygmestermyten og 18. september 1846 samt 28. marts 1848 om Uffe hin Spage.

17 Hans elev N.M Petersen skriver i afhandlingen Den nordiske oldtids betydning for nutiden, 1844, noget lignende: når ideerne i nordisk mytologi som en følge af den nordiske mangel på sanselighed ikke er trådt over i legemlig skikkelse, er det et fortrin for »den kunstner, der ikke vil blive stående ved én gang tilfældig antagne former, men selv vil digte, thi han kan her digte med større frihed «. N.M. Petersen håber på en indsats fra Thorvaldsen og proklamerer: »det er ikke nutidens opgave, at tage oldtiden 
som den er, for at gentage den (da måtte den være givet $\mathrm{i}$ en rig fylde), men det er nutidens opgave, af oldtidens elementer at skabe en ny og rigere tid « - parallelt med den kristelige kunsts »talende, udtryksfulde billeder « af de apostle, hvis ydre og personlighed vi véd så lidt om (Annaler for nordisk Oldkyndighed, 1844-45, s. 54, 55 og 57).

18 Hans Kuhn bemærker i Defining a Nation in Song. Danish Patriotic Songs in Songbooks of the Period 1832-1870, 1990, at de 40 mest populære nationale sange i Danmark 1829-1870 ikke kendetegnes ved fremtrædende historiske elementer - »this may help to explain why Grundtvig, the most productive writer of patriotic poetry, does not hold a more commanding place in this list; many of his poems simply carry too heavy a load of historical (mythological, heraldic) allusion« (s. 259).

19 Georg Brandes: Levned. Barndom og første Ungdom, 1905, s. 127-129. Det er dog opsigtsvækkende, at Julius Lange i tidsskriftet Nutids-Kunst, 1873, i en anmeldelse af den nordiske udstilling $\mathrm{i}$ København året før håber på kunstnerisk genbrug af nordisk mytologi, eftersom den nordiske stamme stadig ejer den profil, som skabte myterne (citeret af Per Dahl i Guder og helte - sort på hvidt. Dansk-norsk bogillustration omkring århundredskiftet i "Laserne«. Studier $i$ den dansk-norske felleslitteratur etter 1814, ved Sigurd Aa. Aarnes, 1994, s. 211).

${ }^{20}$ Emnet er sidst udførligt behandlet af kunsthistorikeren Bo Grandien i Rönndruvans glöd. Nygöticistiskt i tanke, konst och miljö under 1800-talet. Nordiska museets handlingar 107, 1987. Høyens forelæsninger over nordisk-mytologisk kunst er behandlet i Kirsten Agerbæk: Høyen mellem klassicisme og romantik, 1984.

${ }^{21}$ Emnet er udførligt behandlet i Jens Peter Ægidius: Bragesnak, 1-2, 198592.

${ }^{22}$ Et karakteristisk moderne eksempel er plakatprovoen Mikael Wittes brug af citatet til forsvar for børnepornografi i en tv-diskussion med folketingsmedlem Kresten Poulsgaard i 1980. I Folketingsdebatten 16. januar 1880 om tildeling af forfatterst $\varnothing$ tte til den moderne gennembrudsforfatter Sophus Schandorph diskuterer C. Berg Grundtvigs vending mere rigtigt med modstandere af forslaget (som i øvrigt blev vedtaget med 69 stemmer imod 23, med 4 stemmer-ikke). Berg anholder en skæv tolkning hos redaktør af Fyns Stiftstidende J. Pedersen, moderat venstremand fra Assens-kredsen: »Det ærede Medlem mente nemlig, at Grundtvig ved Frihed for Alt, hvad der stammer fra Aand, først vilde have fastslaaet, hvad der kunde kaldes Aand, og hvad Uaand, og derefter Frihed indenfor det Fastslaaedes Grændser. Det er det Mærkelige, at det ærede Medlem kan komme ind paa en saa 
falsk Logik; thi naar først denne Grændse skal drages, er det ærede Medlem inde paa udvortes Bestemmelser, ensidige Bestemmelser, som det er først at sætte Grændsen og derefter sige: Nu have I Frihed.« Striden drejer sig om Schandorphs livsanskuelse som farlig eller ikke for stat og samfund, og Berg fremhæver i det følgende, at han gerne kalder sig og sine »Lokes Børn« $\mathrm{i}$ erindring om Grundtvigs frihedsbegreb. Han henviser til, at Grundtvig i sin tid voksede gennem åndelige kampe og spørger retorisk: »tro De, at overhovedet nogen aandelig Virksomhed kan udvikle sig, naar man søger at dæmme op imod andre Anskuelser og forhindre de aandelige Brydninger, gjennem hvilke Kræfterne maa udvikles og Sandheden klares?« Pedersen takker ironisk for den belæring, han ikke har bedt om og ikke finder vedkommende. Berg understreger, at i næsten 30 år er forfatterst $\varnothing t t e$ gået ikke til de store fortjenstfulde, men til dem, der har »et vist aandeligt Stempel i Lighed med det regjerende Parti«. Heroverfor bliver han ved det grundtvigske begreb om »den større Frihed til at anerkjende Dygtigheden, hvor den nu findes, uden Hensyn til specielle Anskuelser, som her møder Modstand « (Rigsdagstidende. Forhandlinger paa Folkethinget. 32te ordentlige Samling 1879-1880, især sp. 2401-2402, sp. 2406). Denne debat er behandlet i Lisbeth Worsøe-Schmidts utrykte konferensafhandling fra 1986,

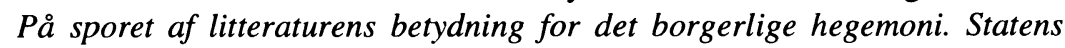
forfatterst $\phi t t e ~ i ~ 70 ' e r n e . ~ 1770 ' e r n e-1870 '$ 'erne - 1970'erne, s. 87-91.

23 Udtrykket »halter« er et citat fra Første Kongebog, 18.21, hvor Elias bruger det om jødernes vaklen imellem Herren og Baal. 